October 31, 2011

Mr. Chad Glenn, Project Manager

U.S. Nuclear Regulatory Commission

Materials Decommissioning Branch

Division of Waste Management and Environmental Protection

TWFN Mail Stop T-8F5

Rockville, MD 20852

\title{
SUBJECT: FINAL-INDEPENDENT CONFIRMATORY SURVEY REPORT FOR THE REACTOR BUILDING, HOT LABORATORY, PRIMARY PUMP HOUSE, AND LAND AREAS AT THE PLUM BROOK REACTOR FACILITY, SANDUSKY, OHIO \\ DCN: 2036-SR-01-0
}

Dear Mr. Glenn:

The Oak Ridge Institute for Science and Education (ORISE) is pleased to provide the enclosed final report that details the confirmatory survey activities that were performed during the week of July 25 , 2011, at the Plum Brook Reactor Facility in Sandusky, Ohio. The survey activities were conducted in accordance with the ORISE confirmatory survey plan provided to and approved by the U.S.

Nuclear Regulatory Commission (NRC). Comments provided on the draft have been addressed.

Please contact me at 865.576 .6659 or Tim Vitkus as 865.576 .5073 should you have any questions.

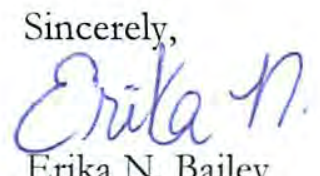

Erika N. Bailey

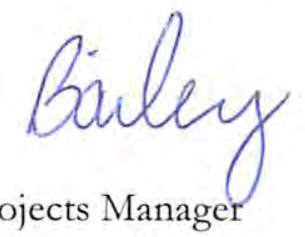

Deputy Survey Projects Manage
Independent Environmental

Assessment and Verification

ENB:fr

Enclosure
c: W. Snell, NRC
L. Rodriguez, NRC
J. Tapp, NRC
V. Kurian, NRC
J. Webb, NRC
File/2036

electronic distribution:

S. Roberts, ORISE

T. Vitkus, ORISE 
FINAL - INDEPENDENT

CONFIRMATORY SURVEY REPORT FOR THE REACTOR BUILDING, HOT LABORATORY, PRIMARY PUMP HOUSE, AND LAND AREAS AT THE PLUM BROOK REACTOR FACILITY, SANDUSKY, OHIO

\section{Erika N. Bailey}

Prepared for the

U.S. Nuclear Regulatory Commission

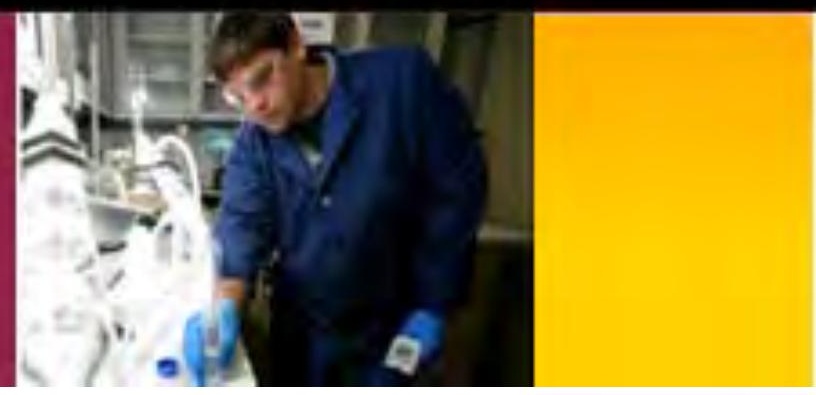

Approved for public release; further dissemination unlimited. 
The Oak Ridge Institute for Science and Education (ORISE) is a U.S. Department of Energy institute focusing on scientific initiatives to research health risks from occupational hazards, assess environmental cleanup, respond to radiation medical emergencies, support national security and emergency preparedness, and educate the next generation of scientists. ORISE is managed by Oak Ridge Associated Universities.

\section{NOTICES}

The opinions expressed herein do not necessarily reflect the opinions of the sponsoring institutions of Oak Ridge Associated Universities.

This report was prepared as an account of work sponsored by the United States Government. Neither the United States Government nor the U.S. Department of Energy, nor any of their employees, makes any warranty, expressed or implied, or assumes any legal liability or responsibility for the accuracy, completeness, or usefulness of any information, apparatus, product, or process disclosed, or represents that its use would not infringe on privately owned rights. Reference herein to any specific commercial product, process, or service by trade name, mark, manufacturer, or otherwise, does not necessarily constitute or imply its endorsement or recommendation, or favor by the U.S. Government or any agency thereof. The views and opinions of authors expressed herein do not necessarily state or reflect those of the U.S. Government or any agency thereof. 


\title{
FINAL - INDEPENDENT CONFIRMATORY SURVEY REPORT FOR THE REACTOR BUILDING, HOT LABORATORY, PRIMARY PUMP HOUSE, AND LAND AREAS AT THE PLUM BROOK REACTOR FACILITY, SANDUSKY, OHIO
}

\author{
Prepared by \\ E. N. Bailey

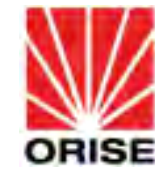 \\ Independent Environmental Assessment and Verification Program \\ Oak Ridge Institute for Science and Education \\ Oak Ridge, Tennessee 37831-0017 \\ Prepared for the \\ U.S. Nuclear Regulatory Commission
}

FINAL REPORT

OCTOBER 2011

Prepared by the Oak Ridge Institute for Science and Education, under interagency agreement (NRC FIN No. F1008) between the U.S. Nuclear Regulatory Commission and the U.S. Department of Energy. The Oak Ridge Institute for Science and Education performs complementary work under contract number DE-AC05-06OR23100 with the U.S. Department of Energy. 


\section{FINAL - INDEPENDENT CONFIRMATORY SURVEY REPORT FOR THE REACTOR BUILDING, HOT LABORATORY, PRIMARY PUMP HOUSE, AND LAND AREAS AT THE PLUM BROOK REACTOR FACILITY SANDUSKY, OHIO}

Prepared by:

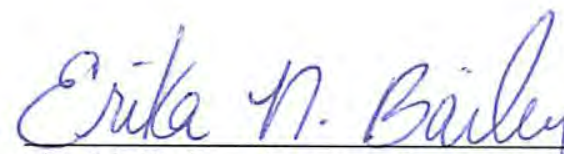

Date:

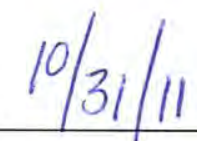

E. N. Bailey, Deputy Survey Pł申jects Manager

Independent Environmental Assessment and Verification Program

Reviewed by:

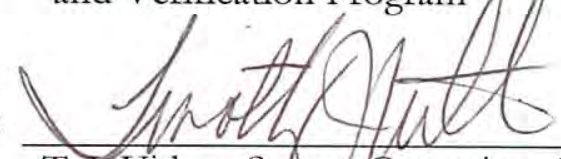

T.J. Vitkus, Suafvey Operations Director

Independent Environmental Assessment and Verification Program

Reviewed by: Wade f. Wre

Date: $10 / 31 / 11$

W. P. Ivey, Laboratory Group Manager Independent Environmental Assessment and Verification Program

Reviewed by:

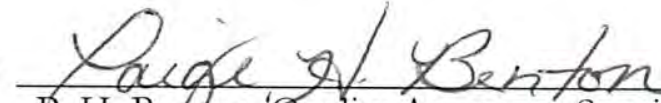

P. H. Benton, Quality Assurance Specialist

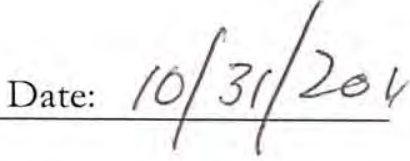
Independent Environmental Assessment and Verification Program 


\section{TABLE OF CONTENTS}

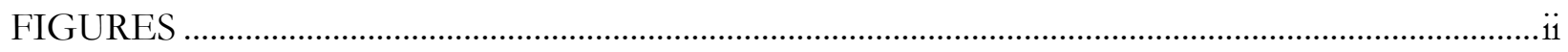

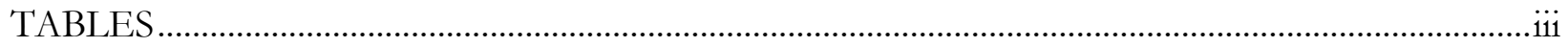

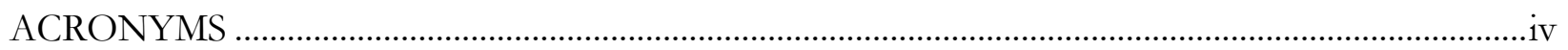

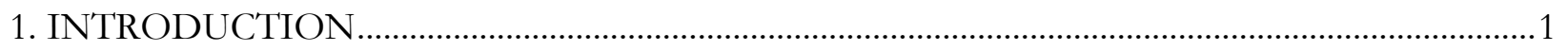

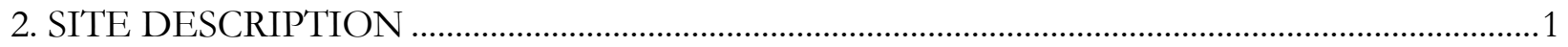

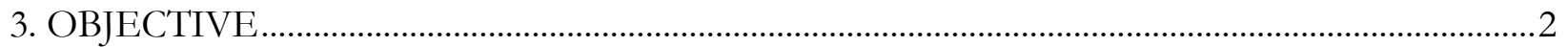

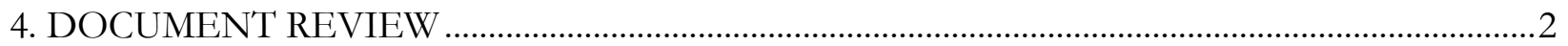

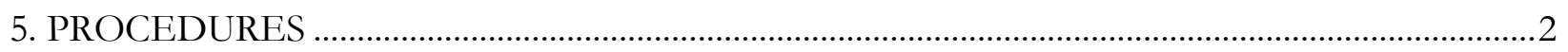

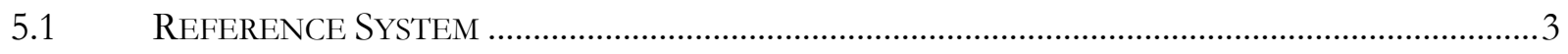

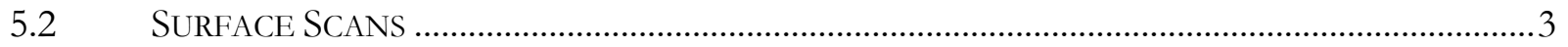

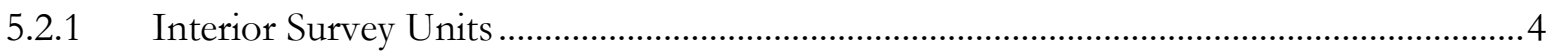

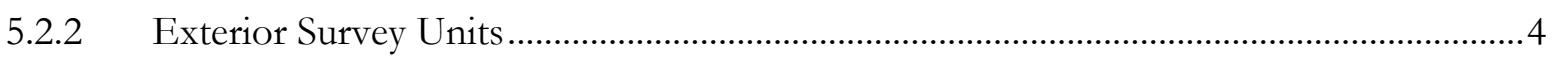

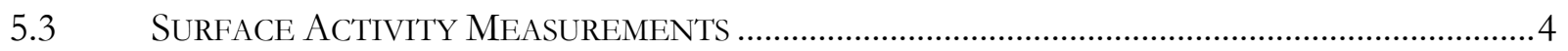

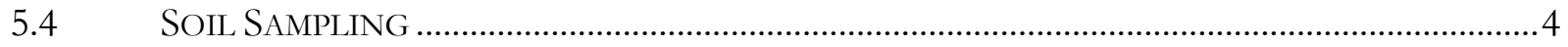

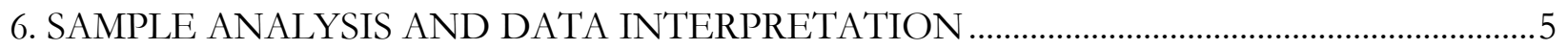

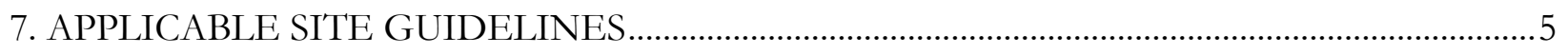

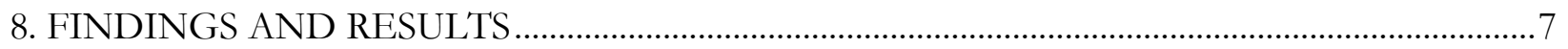

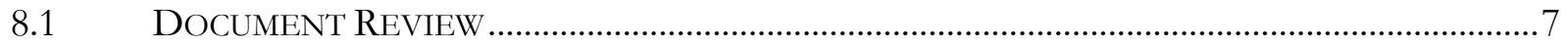

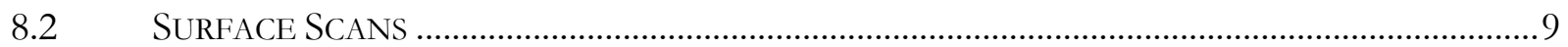

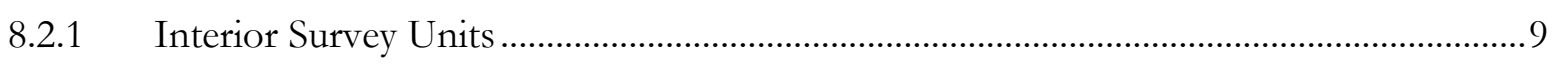

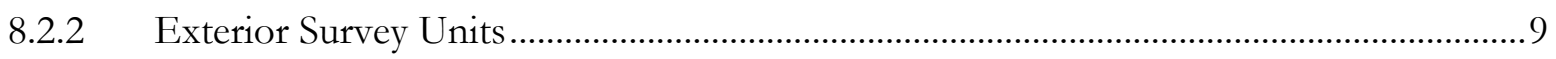

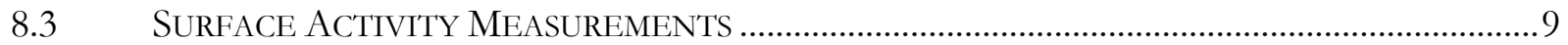

8.4 RADIONUCLIDE CONCENTRATIONS IN SOIL SAMPLES …..................................................

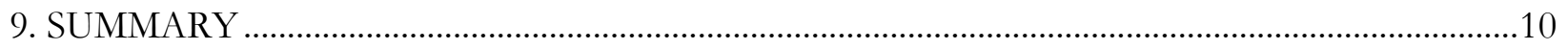

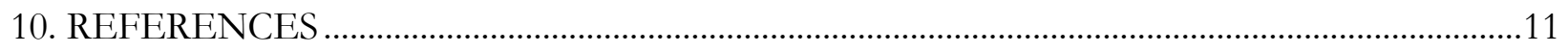

APPENDIX A FIGURES

APPENDIX B TABLES

APPENDIX C MAJOR INSTRUMENTATION

APPENDIX D SURVEY AND ANALYTICAL PROCEDURES 


\section{FIGURES}

Figure A-1. NASA Plum Brook Station Plot Plan ................................................................................ A-1

Figure A-2. CV-3-33 and CV-3-45-Direct Measurement Locations................................................ A-2

Figure A-3. Quad A-Alpha Plus Beta Scans and Direct Measurement Locations.......................... A-3

Figure A-4. Quad A Curved Wall_Alpha Plus Beta Scans and Direct Measurement Locations.... A-4

Figure A-5. RB-4-21 and RB-4-30 (-25 ft elevation)_Direct Measurement Locations .................... A-5

Figure A-6. RB-3-5 (-15 ft elevation)—Direct Measurement Locations .............................................. A-6

Figure A-7. Reactor Building -15 ft elevation-Gamma Scan Histogram ......................................... A-7

Figure A-8. HL-1-64 and HL-1-68_Direct Measurement Locations............................................... A-8

Figure A-9. HL-1-68 — Alpha Plus Beta Scan Histogram................................................................... A-9

Figure A-10. HL-1-70 and HL-1-73-Direct Measurement Locations ........................................... A-10

Figure A-11. HL-1-73 — Alpha Plus Beta Scan Histogram.............................................................. A-11

Figure A-12. HL-1-71 and HL-1-72_Direct Measurement Locations .......................................... A-12

Figure A-13. HL-1-71 and HL-1-72_Alpha Plus Beta Scan Histogram......................................... A-13

Figure A-14. PH-1-20 (Room 8)—Direct Measurement Locations ................................................... A-14

Figure A-15. PH-1-20 (Room 8)—Alpha Plus Beta Scan Histogram............................................... A-15

Figure A-16. PH-1-15 and PH-1-16 (Room 6) -Direct Measurement Locations ...........................A-16

Figure A-17. PH-1-15 and PH-1-16 (Room 6)_Alpha Plus Beta Scan Histogram.........................A-17

Figure A-18. Primary Pump House (Room 4)—Alpha Plus Beta Scans and Direct Measurement

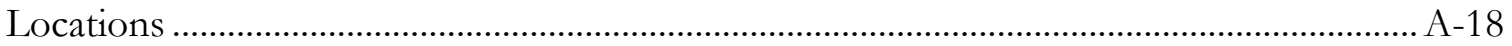

Figure A-19. Hot Laboratory Viewing Gallery_Alpha Plus Beta Scan Histogram........................ A-19

Figure A-20. HL-1-91 Trenches-Soil Sample Locations.............................................................. A-20

Figure A-21. Emergency Retention Basin OL-1-32-Gamma Scans and Soil Sample Locations. A-21

Figure A-22. Emergency Retention Basin OL-1-32_Gamma Scan Histogram ............................. A-22 


\section{TABLES}

Table 1. Applicable Radiological Release Criteria for Surface and Structures at the Plum Brook

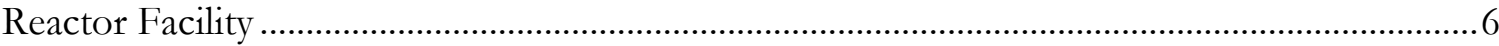

Table 2. Applicable Radiological Release Criteria for Outside Areas at the Plum Brook Reactor

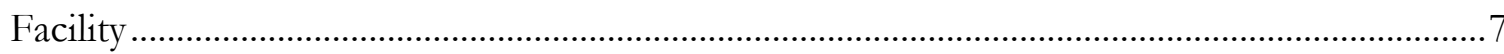

Table B-1. Surface Activity Summary Plum Brook Reactor Facility ....................................................... B-1

Table B-2. Radionuclide Concentrations in Soil Samples Plum Brook Reactor Facility........................4

Table D-1. MDC Derived from Total Absorption Peak ...................................................................... 


\section{ACRONYMS}

DCGL $_{\mathbb{W}} \quad$ derived concentration guideline level

DCGL $_{\mathrm{GB}} \quad$ gross beta derived concentration guideline level

DP decommissioning plan

dpm disintegrations per minute

FSS final status survey

GPS global positioning system

IEAV Independent Environmental Assessment and Verification

MARSSIM Multi-Agency Radiation Survey and Site Investigation Manual

MDC minimum detectable concentration

$\mathrm{MeV} \quad$ million electron volts

NAD North American Datum

$\mathrm{NaI} \quad$ sodium iodide

NASA National Aeronautics and Space Administration

NRC U.S. Nuclear Regulatory Commission

ORAU Oak Ridge Associated Universities

ORISE Oak Ridge Institute for Science and Education

PBRF Plum Brook Reactor Facility

$\mathrm{pCi} / \mathrm{g} \quad$ picocuries per gram

ROC radionuclide of concern

RTS Robotic Total Station

SU survey unit

TAP total absorption peak

DOE U.S. Department of Energy 


\section{FINAL - INDEPENDENT CONFIRMATORY SURVEY REPORT FOR THE REACTOR BUILDING, HOT LABORATORY, PRIMARY PUMP HOUSE, AND LAND AREAS AT THE PLUM BROOK REACTOR FACILITY SANDUSKY, OHIO}

\section{INTRODUCTION}

In 1941, the War Department acquired approximately 9,000 acres of land near Sandusky, Ohio and constructed a munitions plant. The Plum Brook Ordnance Works Plant produced munitions, such as TNT, until the end of World War II. Following the war, the land remained idle until the National Advisory Committee for Aeronautics later called the National Aeronautics and Space Administration (NASA) obtained 500 acres to construct a nuclear research reactor designed to study the effects of radiation on materials used in space flight. The research reactor was put into operation in 1961 and was the first of fifteen test facilities eventually built by NASA at the Plum Brook Station. By 1963, NASA had acquired the remaining land at Plum Brook for these additional test facilities.

After successfully completing the objective of landing humans on the Moon and returning them safely to Earth, NASA was faced with budget reductions from Congress in 1973. These budgetary constraints caused NASA to cease operations at several research facilities across the country, including those at Plum Brook Station. The major test facilities at Plum Brook were maintained in a standby mode, capable of being reactivated for future use. The Plum Brook Reactor Facility (PBRF) was shut down January 5,1973 and all of the nuclear fuel was eventually removed and shipped offsite to a U.S. Department of Energy (DOE) facility in Idaho for disposal or reuse (NASA 1999). Decommissioning and final status survey (FSS) activities are nearly complete at the PBRF.

At the request of the U.S. Nuclear Regulatory Commission (NRC), the Independent Environmental Assessment and Verification (IEAV) Program of the Oak Ridge Institute for Science and Education (ORISE) conducted confirmatory survey activities at the PBRF. The ORISE contract is managed by Oak Ridge Associated Universities (ORAU) for the DOE.

\section{SITE DESCRIPTION}

The Plum Brook Station, named for the creek that runs through the site, is south of the town of Sandusky, Ohio and is surrounded by farmlands and low density residential housing. Approximately 
5,400 acres of the Plum Brook Station are enclosed within a security fence. Individual security fences surround several of the test sites including the PBRF. The PBRF originally consisted of numerous buildings within a 27-acre fenced area (NASA 2008); however, currently only the Reactor Building, the Hot Lab, Primary Pump House, and an office support building remain. Figure A-1 shows the Plum Brook site plot plan and associated identifications of buildings and land areas.

\section{OBJECTIVE}

The objective of the confirmatory survey activities was to verify that the final radiological conditions were accurately and adequately described in FSS documentation, relative to the established release criteria. This objective was achieved by performing document reviews, as well as independent measurements and sampling. Specifically, documentation of the planning, implementation, and results of the FSS were evaluated and Survey Units (SUs) were assessed for residual, undocumented contamination.

\section{DOCUMENT REVIEW}

Prior to on-site activities, ORISE was tasked with reviewing the Decommissioning Plan for the Plum Brook Reactor Facility, Revision 6, and the Final Status Survey Plan, Revision 1 (NASA 2008 and 2007a). ORISE also reviewed select survey unit release records for the SUs of interest that were available prior to confirmatory activities. The SU release records were specifically reviewed to identify the radionuclides of concern (ROCs), associated radionuclide fractions, and the applicable gross beta derived concentration guideline level $\left(\mathrm{DCGL}_{\mathrm{GB}}\right)$ values for each SU. ORISE also reviewed NASA's technical basis document of calculated gross beta DCGL $_{\mathrm{GB}}$ values for structural surfaces for areas of the buildings where multiple radionuclides were present (NASA 2007b). All documents and data were reviewed for adequacy and appropriateness, taking in to account the Decommissioning Plan and Multi-Agency Radiation Survey and Site Investigation Manual (MARSSIM) guidance (NASA 2008 and NRC 2000).

\section{PROCEDURES}

At the request of the NRC, the ORISE survey team visited the PBRF during the week of July 25, 2011, to perform confirmatory survey activities. Confirmatory survey activities included the review of additional survey unit release records, visual inspection, surface scans, surface activity 
measurements, and sample collection. The ORISE survey team performed various confirmatory survey activities within select SUs in the following areas:

- The inner bioshield, Quads A through D, -15 ft. and -25 ft. elevations of the Reactor Building

- Rooms 4, 6, and 8 in the Primary Pump House

- Viewing gallery, hot cells, and soil trenches within the Hot Laboratory Building

- Emergency retention basin

The confirmatory survey activities were conducted in accordance with a project-specific plan, the ORISE/IEAV Survey Procedures Manual and Quality Program Manual (ORISE 2011b, ORISE 2008, ORAU 2011). Questions and concerns were brought to the immediate attention of the NRC and are also noted in the Findings and Results section of this report.

\subsection{REFERENCE SYSTEM}

Indoor measurement locations were referenced to prominent site features and documented on site drawings provided by the licensee. A Trimble Robotic Total Station (RTS) was used to capture and document the spatial reference data for confirmatory activities in Quad A in the Reactor Building and Room 4 in the Primary Pump House. Exterior land area scans were referenced using Global Positioning System (GPS) coordinates and also documented on site drawings provided by the licensee. The coordinate reference system used for the confirmatory survey was: North American Datum (NAD) 1983 State Plane Ohio North FIPS 3401 with units represented in meters.

\subsection{SURFACE SCANS}

FSS results were considered to determine the level of confirmatory survey effort required to adequately represent each SU or to identify specific areas to focus scans within the SU. Interior building scans covered floors, lower walls, and accessible upper surfaces while exterior scans focused on the southwest section of the emergency retention basin. The surface scan coverage of the areas selected for confirmatory surveys varied based on the size and accessibility of the areas. Low- to high-density scans were performed and focused in areas with the highest potential for contamination (i.e., cracks and joints in the floor and walls, remediated areas, other horizontal surfaces, and other potential accumulation areas). 


\subsubsection{Interior Survey Units}

Interior SU surfaces including floors, lower walls, and other accessible surfaces were scanned using hand-held, gas proportional detectors for direct alpha plus beta radiation. Additionally, all floor surfaces were scanned for gamma radiation using sodium iodide $(\mathrm{NaI})$ detectors. All detectors were coupled to ratemeter-scalers with audible indicators. The RTS was used to record and map scan data and direct measurement locations within Quad A in the Reactor Building and Room 4 in the Primary Pump House. Data loggers were coupled to other instrument/detector combinations during scans. The observed count rates were recorded in one-second intervals. The Appendix A figure sequence A-2 through A-20 includes figures that show the interior survey unit information.

\subsubsection{Exterior Survey Units}

Exterior SU surfaces were scanned for direct gamma radiation using $\mathrm{NaI}$ scintillation detectors coupled to ratemeter-scalers with audible indicators coupled to a GPS unit that enabled real-time recording of both position and count rates in one-second intervals. Figures A-21 and 22 present the exterior gamma scan results for SU OL-1-32 associated with the emergency retention basin.

\subsection{Surface ACtivity Measurements}

Direct measurements to quantify total alpha plus beta activities were performed at judgmental locations using hand-held gas proportional detectors coupled to ratemeter-scalers. As specified in the project-specific plan, a minimum of three direct measurements were collected from the highest radiation levels observed within selected SUs, even if scans did not identify radiation levels that would be in excess of the $\mathrm{DCGL}_{\mathrm{GB}}$ value within the particular SU. A few additional direct measurements were collected as well. A smear sample was also collected from the majority of the direct measurement locations to determine removable gross alpha and gross beta activity levels. The Appendix A figure sequence A-2 through A-20 includes figures that show the interior survey unit information.

\subsection{SOIL SAMPLING}

ORISE collected four soil samples at judgmental locations. Sample locations were selected based on gamma radiation levels detected during scans (with the exception of S0004). Samples S0001 and S0002 were collected from SU HL-1-91 in the soil trenches located beneath the floor of the Hot 
Laboratory Warm Work Area (Figure A-20). Sample S0003 was collected from SU OL-1-32 (Figure A-21). As requested by the NRC, sample S0004 was collected from the $-15 \mathrm{ft}$. elevation of the Reactor Building. This sample consisted of mud that was seeping from outside into the sump area.

Additionally as requested by the NRC, the licensee provided ORISE with sample number SR-277-3 (ORISE sample S0005) collected from an investigation location in SU OL-1-27 for comparison analysis. This sample contained the highest concentration of cesium-137 (Cs-137) from the soil samples collected from that particular SU but was still below the DCGL $\mathrm{W}_{\mathrm{W}}$.

\section{SAMPLE ANALYSIS AND DATA INTERPRETATION}

Samples and data were returned to the ORISE facility in Oak Ridge, Tennessee for analysis and interpretation. All sample analyses were performed in accordance with the ORISE Laboratory Procedures Manual (ORISE 2011a). Smear samples collected for the quantification of gross alpha/beta activity were analyzed using a low-background proportional counter. Analytical smear sample results were reported in units of disintegrations per minute per one hundred square centimeters $\left(\mathrm{dpm} / 100 \mathrm{~cm}^{2}\right)$. Direct measurement data were converted from counts per minute (cpm) to units of $\mathrm{dpm} / 100 \mathrm{~cm}^{2}$ using the appropriate radionuclide mixture and weighted efficiency for each SU. All soil samples were analyzed by gamma spectroscopy for gamma-emitting fission and activation products and three were selected for strontium-90 (Sr-90) analysis. The gamma spectroscopy and Sr-90 results were reported in units of picocuries per gram (pCi/g). The data generated were compared with the guidelines established for the Plum Brook site (listed in Tables 1, 2 and B-1).

\section{APPLICABLE SITE GUIDELINES}

The primary contaminants of concern for the PBRF are beta-gamma emitters-fission and activation products - resulting from reactor operation. Alpha contamination has been identified in specific areas of the site.

The DCGL $L_{\mathbb{W}}$ values for structures are listed in Table 1 (NASA 2007a). The DCGL $\mathrm{W}_{\mathbb{W}}$ values are the surface activity levels in $\mathrm{dpm} / 100 \mathrm{~cm}^{2}$ used to evaluate FSS measurements to determine compliance with the 25 millirem per year (mrem/yr) unrestricted use criterion. 


\begin{tabular}{|c|c|}
\hline $\begin{array}{r}\text { I able 1. Apr } \\
\text { for } \\
\text { P1 }\end{array}$ & $\begin{array}{l}\text { Facility } \\
\text { Fas at the }\end{array}$ \\
\hline Radionuclide & $\operatorname{DCGL}_{w}\left(\mathrm{dpm} / 100 \mathrm{~cm}^{2}\right)$ \\
\hline Co-60 & 11,000 \\
\hline Sr-90 & 33,100 \\
\hline Cs-137 & 40,500 \\
\hline Eu-154 & 4,500 \\
\hline H-3 & $9.1 \mathrm{E}+06$ \\
\hline $\mathrm{I}-129$ & 14,900 \\
\hline $\mathrm{U}-234$ & 31,500 \\
\hline U-235 & 27,100 \\
\hline U-236 & 33,200 \\
\hline
\end{tabular}

During site characterization activities, the licensee determined the specific radionuclide mixtures and fractions present in the various areas of the site via sample analyses of concrete cores, smears, and other media samples. The licensee calculated $\mathrm{DCGL}_{\mathrm{GB}}$ values because multiple radionuclides were present in different fractional quantities in various areas of the buildings (NASA 2007b). This approach enables field measurements of gross activity rather than the determination of individual radionuclide activity for comparison to the radionuclide-specific DCGL $\mathrm{W}_{\mathrm{W}}$. Cs-137 was selected as the surrogate for the hard-to-detect (HTD) nuclides, tritium (H-3) and iodine (I-129), and the DCGLs were modified appropriately. The entire list of calculated DCGL $\mathrm{GB}_{\mathrm{B}}$ values can be found in the NASA technical basis document regarding adjusted DCGLs for structural surfaces (NASA 2007b). However, in some cases the DCGLs were actually reduced further to account for deselected nuclides and embedded/buried pipes; the final DCGL $\mathrm{GB}_{\mathrm{G}}$ values are reported in the specific survey unit release record and included with the data presented in Table B-1 of this report.

The gross beta DCGL $_{\mathrm{GB}}$ values were calculated using the following equation:

$$
D C G L_{G B}=\frac{1}{\left(\frac{f_{1}}{D C G L_{W 1}}\right)+\left(\frac{f_{2}}{D C G L_{W 2}}\right)+\left(\frac{f_{3}}{D C G L_{W 3}}\right)+\left(\frac{f_{n}}{D C G L_{W n}}\right)},
$$

where DCGL $\mathrm{DB}_{\mathrm{GB}}=$ gross beta DCGL, 
$\mathrm{f}_{\mathrm{n}}=$ mixture fraction of radionuclide $n$, and

$\mathrm{DCGL}_{\mathrm{Wn}}=\mathrm{DCGL}_{\mathbb{W}}$ of radionuclide $n$.

Removable activity guidelines are set at $10 \%$ or less of the DCGL $L_{\mathbb{W}}$ values consistent with the assumptions made during structural dose modeling development (NASA 2007a).

The surface soil DCGLs are listed in Table 2. The soil DCGL values are the volumetric activity of the first 15 centimeters $(\mathrm{cm})$ of soil, in units of $\mathrm{pCi} / \mathrm{g}$, that will be used for FSS samples to determine compliance with the $25 \mathrm{mrem} / \mathrm{yr}$ unrestricted use criterion (NASA 2007a). The Cs-137 DCGL D $_{\mathbb{W}}$ was appropriately modified (lowered) to be used as the surrogate for Sr-90. The unity rule (also known as the sum of fractions) must also be met.

\begin{tabular}{|c|c|}
\hline $\mathbf{P}$ & ility \\
\hline Radionuclide & $\mathrm{DCGL}_{\mathrm{w}}(\mathrm{pCi} / \mathrm{g})$ \\
\hline Co-60 & 3.8 \\
\hline Sr-90 & 5.4 \\
\hline Cs-137 & 14.7 \\
\hline
\end{tabular}

\section{FINDINGS AND RESULTS}

The results for each of the confirmatory activities are discussed in the following subsections.

\subsection{Document REVIEW}

The initial ORISE reviews of the licensee's project documentation indicated that the FSS methods were appropriate and that the resultant data were acceptable. However, after confirmatory surveys were complete and ORISE was performing final direct measurement calculations from cpm to $\mathrm{dpm} / 100 \mathrm{~cm}^{2}$ for this report, a potential issue was identified. In several of the SUs, uranium-234 (U-234) comprises a significant fraction of the radionuclide mixture [uranium-235 (U-235) at a lesser fraction]. While ORISE had collected alpha plus beta measurements and could account for this, the ORISE Project Manager recalled that the licensee collected beta only measurements and could not identify project documentation regarding the licensee applying surrogate calculations to a measurable 
beta ROC or performing separate alpha measurements. If the intent of collecting beta-only measurements was to use a beta-emitting nuclide as a surrogate for the U-234 (or U-235), then the $\mathrm{DCGL}_{\mathrm{GB}}$ values should have been adjusted further (lowered) for areas of the site with significant U-234 and U-235 in the radionuclide mixture. The following calculations for Area 20 of the Reactor Building are being provided as an informational example.

\section{Area 20 (radionuclide mixture of $48.4 \%$ Cs-137 and 51.6\% U-234):}

The DCGL $\mathrm{GB}_{\mathrm{G}}$ value listed in PBRF-TBD-07-001 is calculated (using the equation listed in Section 5.2 .2 of the technical basis document) as:

$$
D C G L_{G B}=\frac{1}{\left(\frac{0.484}{40,500}\right)+\left(\frac{0.516}{31,500}\right)}=35,296 \mathrm{dpm} / 100 \mathrm{~cm}^{2} .
$$

In the survey unit release record for SU RB-3-5 in Area 20 in which ORISE performed confirmatory measurements, the DCGL ${ }_{\mathrm{GB}}$ was lowered slightly to $30,355 \mathrm{dpm} / 100 \mathrm{~cm}^{2}$ to account for "deselected nuclides and embedded/buried pipe."

However, because beta only measurements were performed, the licensee should have performed a surrogate calculation for the U-234. In this case, the option would be to select Cs-137 as the surrogate and the modified Cs-137 guideline to account for the U-234 would be:

$$
\operatorname{DCGL}(\text { Cs }-137 \mathrm{mod})=40,500 * \frac{31,500}{\left[\left(\frac{0.516}{0.484}\right) * 40,500\right]+31,500}=17,084 \mathrm{dpm} / 100 \mathrm{~cm}^{2}
$$

This results in a much lower $\mathrm{DCGL}_{\mathrm{GB}}(>50 \%$ reduction) for this area alone and could potentially result in some of the FSS data being above this value.

In the example provided for Area 20, it is important to note that the modified Cs-137 value accounts for $100 \%$ of the mixture in this specific case. In other areas of the site where there are additional alpha- and beta-emitting radionuclides comprising the mixture, the total gross beta DCGL would still need to be calculated per the equation on page 6 using any modified DCGLs to account for the alpha emitters as well as accounting for any additional beta emitters. 


\subsection{SURFACE SCANS}

Surface scan results for the interior and exterior SUs are discussed below.

\subsubsection{Interior Survey Units}

Surface scans of the selected SUs did not identify radiation levels of concern above the reported DCGL $_{\mathrm{GB}}$ values. The maximum scan results for each SU were above background levels but still below the reported $\mathrm{DCGL}_{\mathrm{GB}}$ values.

\subsubsection{Exterior Survey Units}

Figure A-21 and A-22 show the exterior gamma scan results for the accessible areas of SU OL-1-32 associated with the emergency retention basin. The inaccessible areas contained puddled water due to recent rainfall. The histogram in Figure A-22 reveals two distinct background populations for the SU. No anomolies were identified and all data was within the expected background distribution.

\subsection{Surface ACTIVITY MEASUREMENTS}

Table B-1 provides surface activity measurements and represents gross levels that have not had background contributions subtracted, per the licensee's FSS data reporting procedure. The final DCGL $_{\mathrm{GB}}$ values, as reported in the specific survey unit release records, are referenced for comparison. All the confirmatory measurements fell below the reported DCGL $\mathrm{GB}_{\mathrm{G}}$ values for each SU. Additionally, laboratory analysis of the smears did not identify removable alpha or beta contamination.

\subsection{RADIONUCLIDE CONCENTRATIONS IN SOIL SAMPLES}

Table B-2 provides the soil sample results. All concentrations were below the applicable $\mathrm{DCGL}_{\mathbb{W}} \mathrm{S}$ for soils. Soil sample S0005 was given to ORISE for laboratory comparison analysis. The licensee's reported Cs-137 and Cobalt-60 (Co-60) results were 4.29 pCi/g and < minimum detectable activity (MDA), respectively. The ORISE results were comparable at 4.62 and $0.06 \mathrm{pCi} / \mathrm{g}$. The unity rule was met for all soil samples as well. 


\section{SUMMARY}

At the request of the NRC, ORISE conducted confirmatory survey activities at the PBRF during the week of July 25, 2011. The survey activities included document review, visual inspections/ assessments, and measurement and sampling activities.

All ORISE smear and soil sample data met the approved release criteria. Additionally, the ORISE surface activity data verifies the radiological conditions of the confirmatory SUs are below the DCGL $_{\mathrm{GB}}$ values as currently reported in the SU release records. However, due to the finding discussed in Section 8.1, ORISE recommends that the licensee perform the following investigations:

- Re-evaluate the $\mathrm{DCGL}_{\mathrm{GB}}$ values that may be affected in areas of the site with a significant fraction of $\mathrm{U}-234 / 235$ in the radionuclide mixture and revise the DCGL $\mathrm{GB}_{\mathrm{B}}$ values if there is concurrence with ORISE's assessment.

- Identify and review all FSS packages that would be impacted by the revised DCGL $\mathrm{GB}_{\mathrm{GB}}$ values and determine if the final reported beta measurements are below the revised DCGL ${ }_{G B}$ values. 


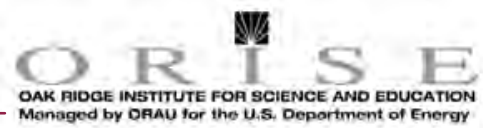

\section{REFERENCES}

National Aeronautics and Space Administration (NASA). The History of NASA's Plum Brook Station. Sandusky, Ohio. June 1999.

National Aeronautics and Space Administration. Final Status Survey Plan for the Plum Brook Reactor Facility, Revision 1. Sandusky, Ohio. February 8, 2007 a.

National Aeronautics and Space Administration. Adjusted Gross DCGLs for Structural Surfaces PBRFTBD-07-001. Revision 0. Sandusky, Ohio. June 5, 2007b.

National Aeronautics and Space Administration. Decommissioning Plan for the Plum Brook Reactor Facility, Revision 6. Sandusky, Ohio. July 23, 2008.

Oak Ridge Associated Universities (ORAU). Quality Program Manual for the Independent Environmental Assessment and Verification Program. Oak Ridge, Tennessee. May 10, 2011.

Oak Ridge Institute for Science and Education (ORISE). Survey Procedures Manual for the Independent Environmental Assessment and Verification Program. Oak Ridge, Tennessee. May 1, 2008.

Oak Ridge Institute for Science and Education. Laboratory Procedures Manual for the Independent Environmental Assessment and Verification Program. Oak Ridge, Tennessee. April 28, $2011 \mathrm{a}$.

Oak Ridge Institute for Science and Education. Final Project-Specific Plan for Independent Confirmatory Survey Activities Associated with the Reactor Building, Hot Lab, Primary Pumphouse, and Land Areas at the Plum Brook Reactor Facility, Sandusky, Obio. Oak Ridge, Tennessee. July 21, 2011b.

U.S. Nuclear Regulatory Commission (NRC). Multi-Agency Radiation Survey and Site Investigation Manual (MARSSIM), NUREG-1575; Revision 1. Washington, DC. August, 2000. 
APPENDIX A

FIGURES

Plum Brook Reactor Facility

2036-SR-01-0 


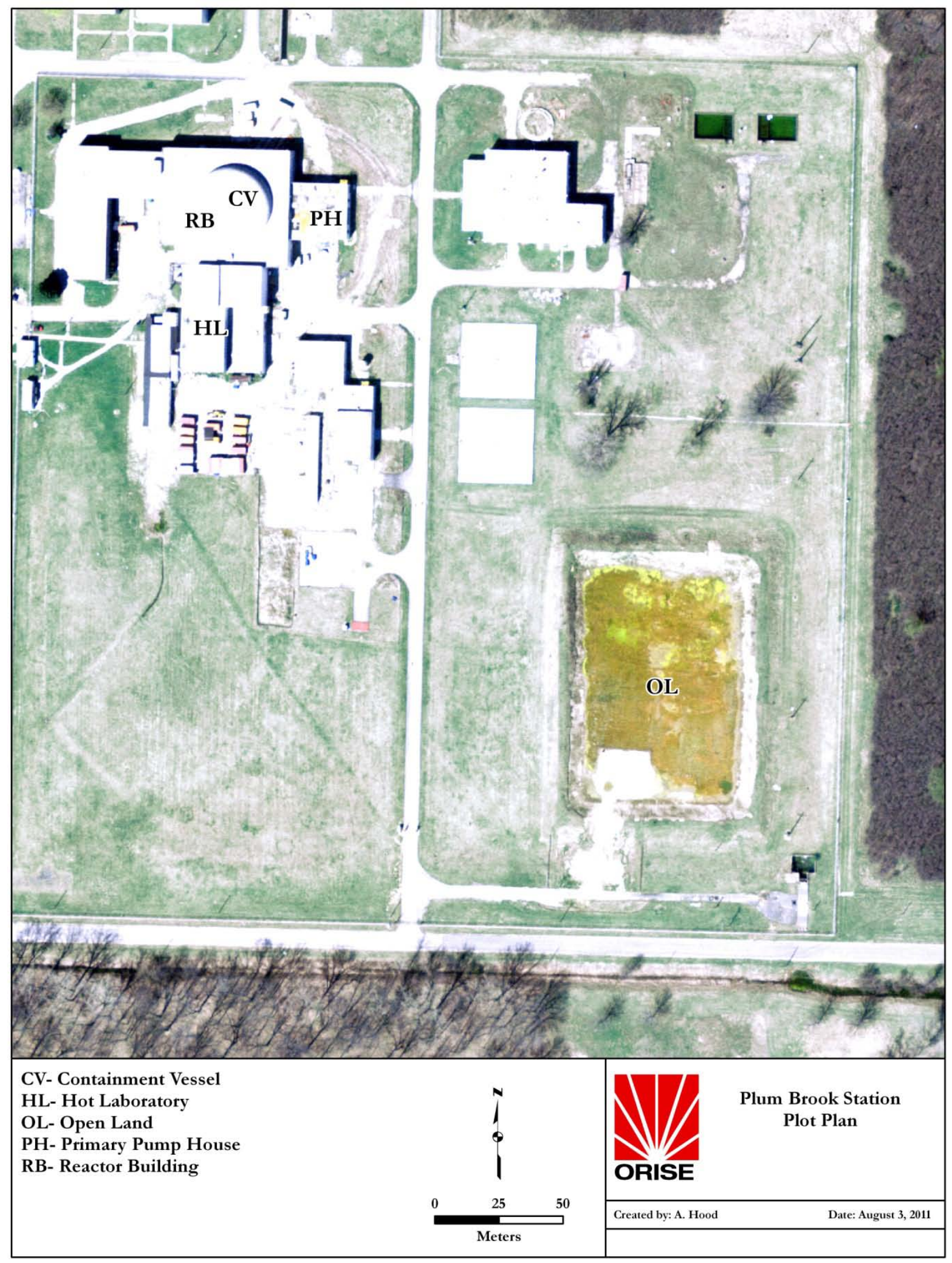

Figure A-1. NASA Plum Brook Station Plot Plan 


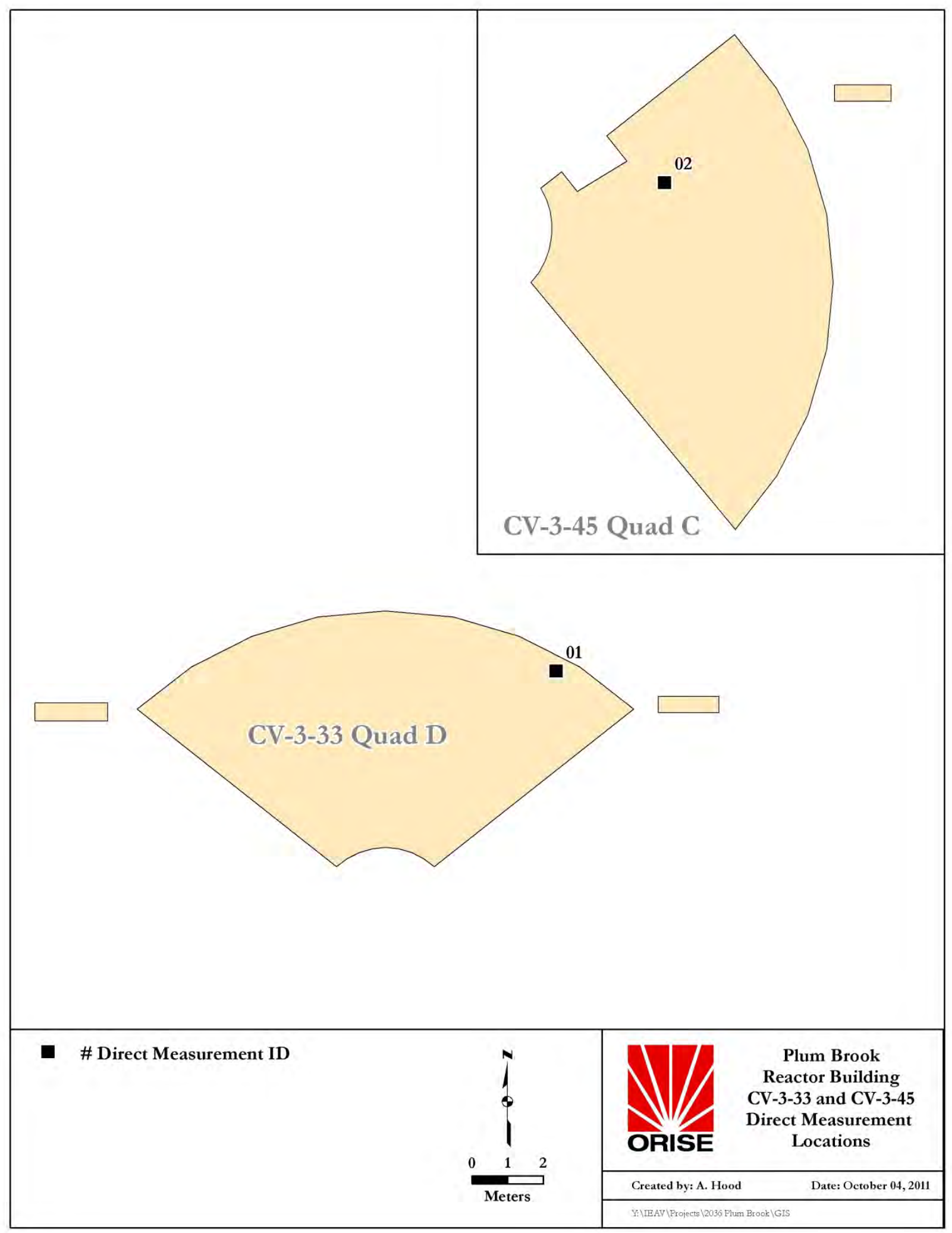

Figure A-2. CV-3-33 and CV-3-45-Direct Measurement Locations 


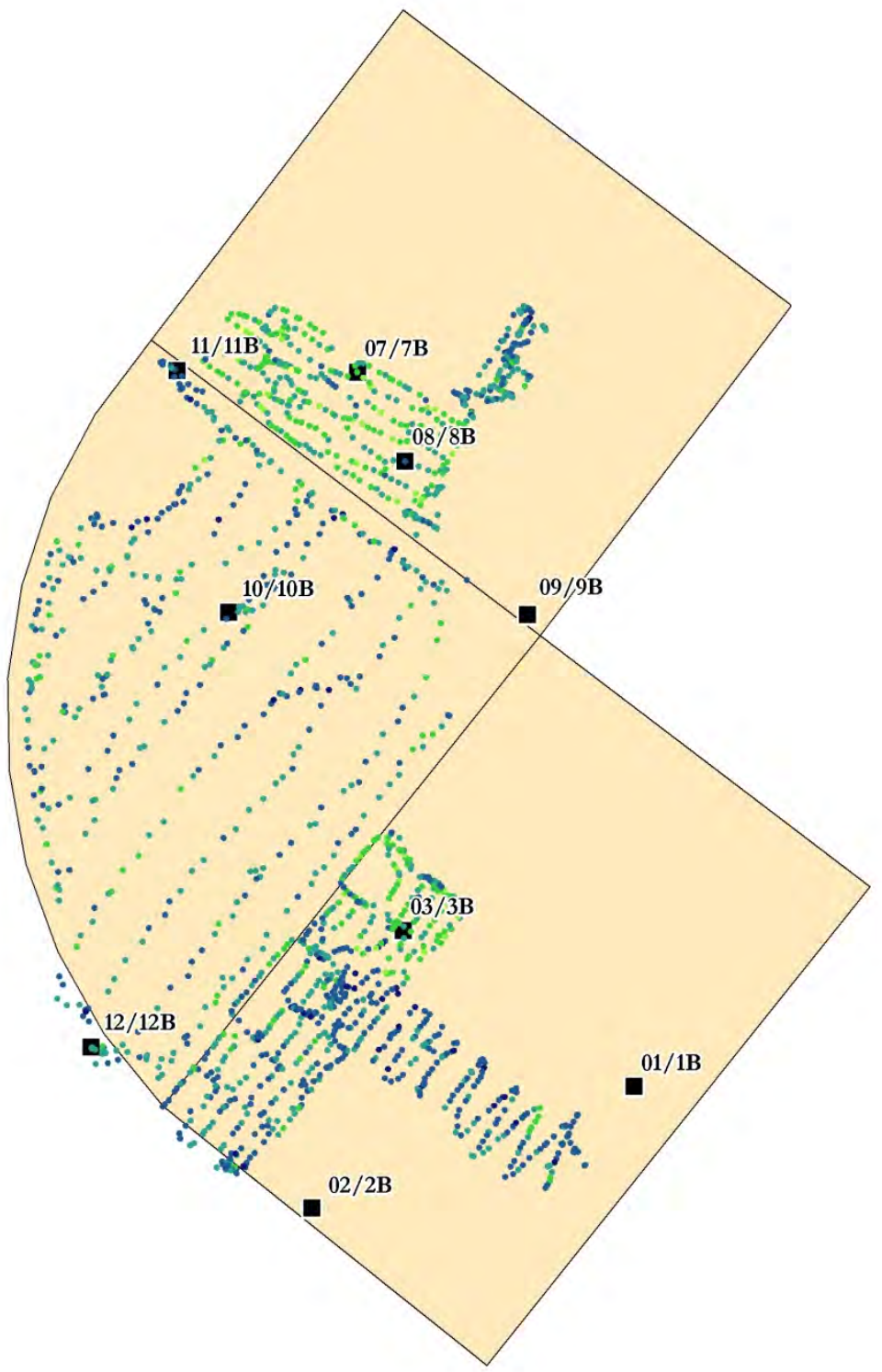

- Direct Measurement ID/Smear ID

Alpha + Beta Count Rate (cpm)

\begin{tabular}{ll}
$501-550$ & \\
$401-500$ & $101-200$ \\
$301-400$ & $<100$ \\
$201-300$ & \\
\hline
\end{tabular}

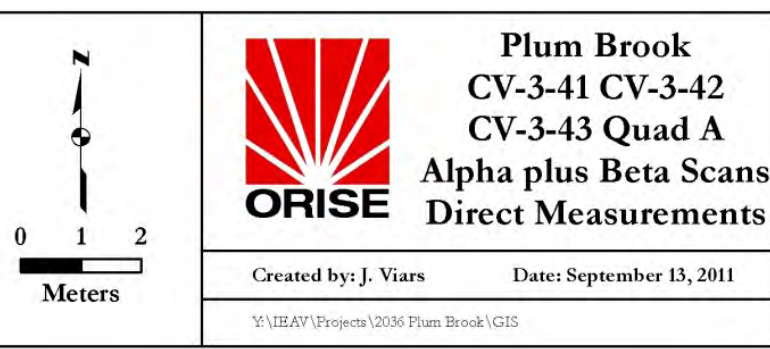

Figure A-3. Quad A-Alpha Plus Beta Scans and Direct Measurement Locations 


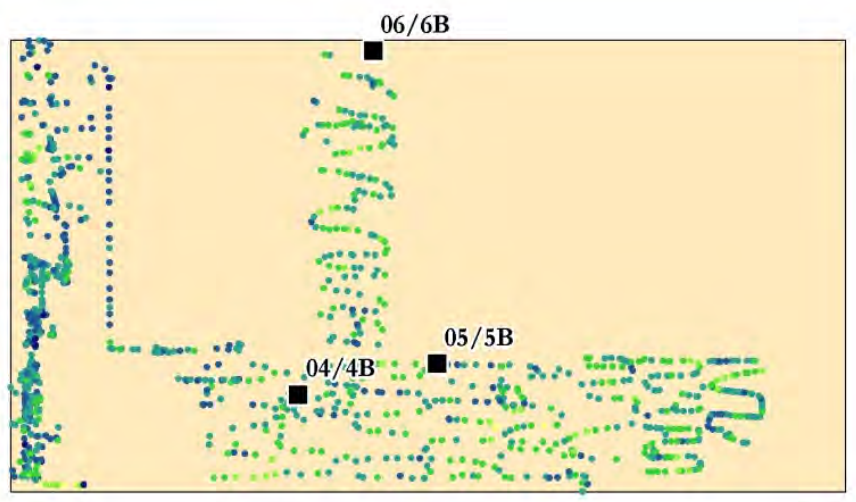

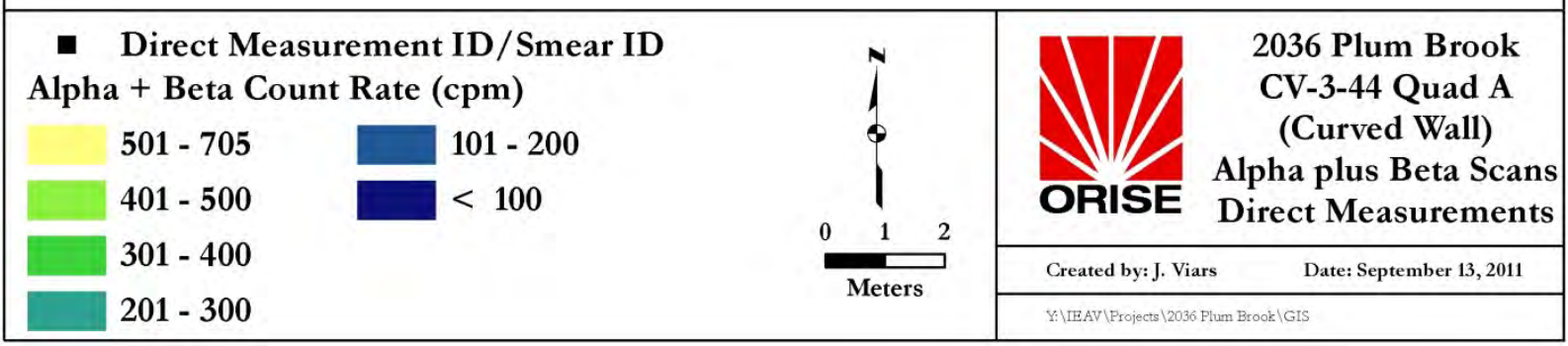

Figure A-4. Quad A Curved Wall-Alpha Plus Beta Scans and Direct Measurement Locations 


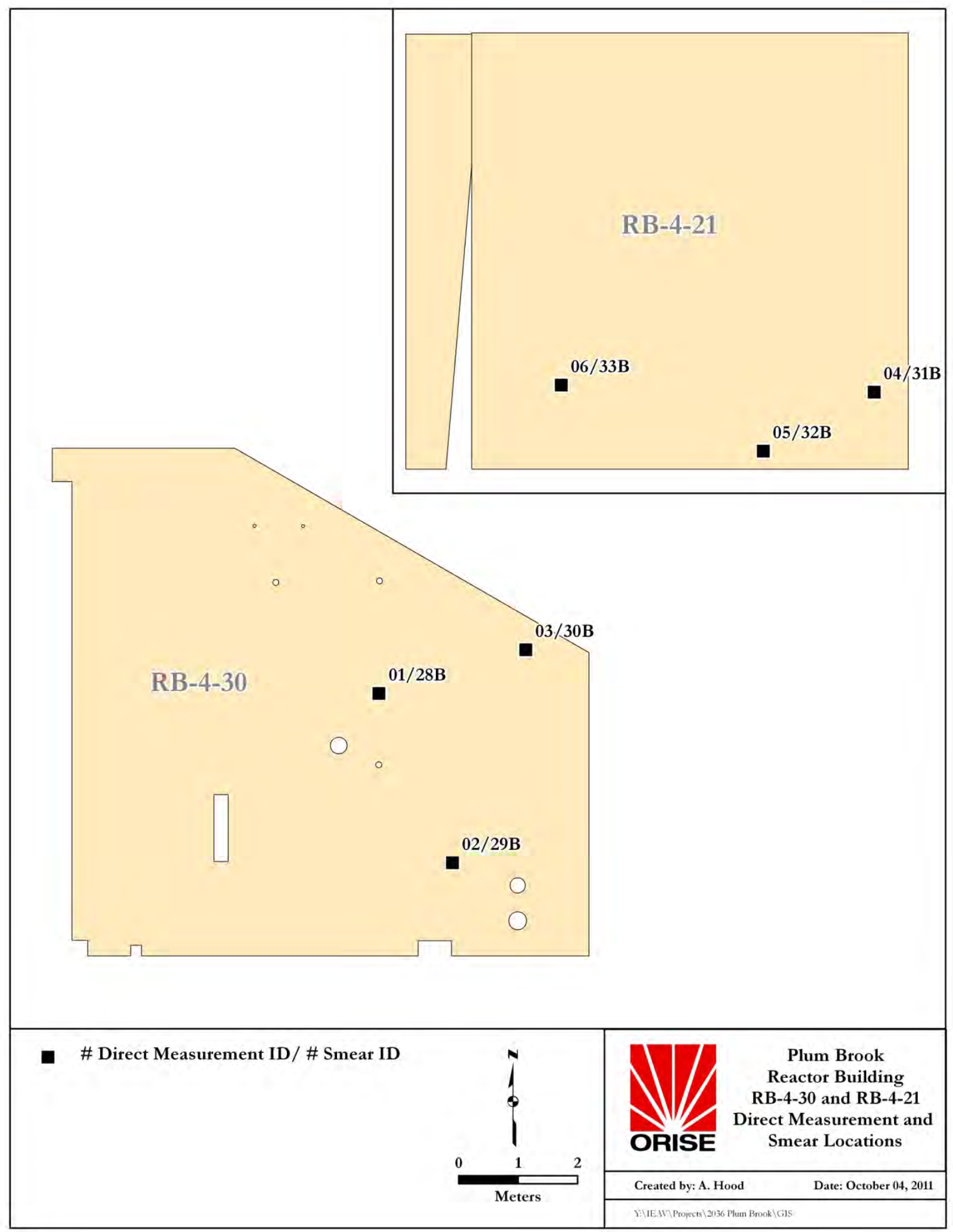

Figure A-5. RB-4-21 and RB-4-30 (-25 ft elevation)-Direct Measurement Locations 


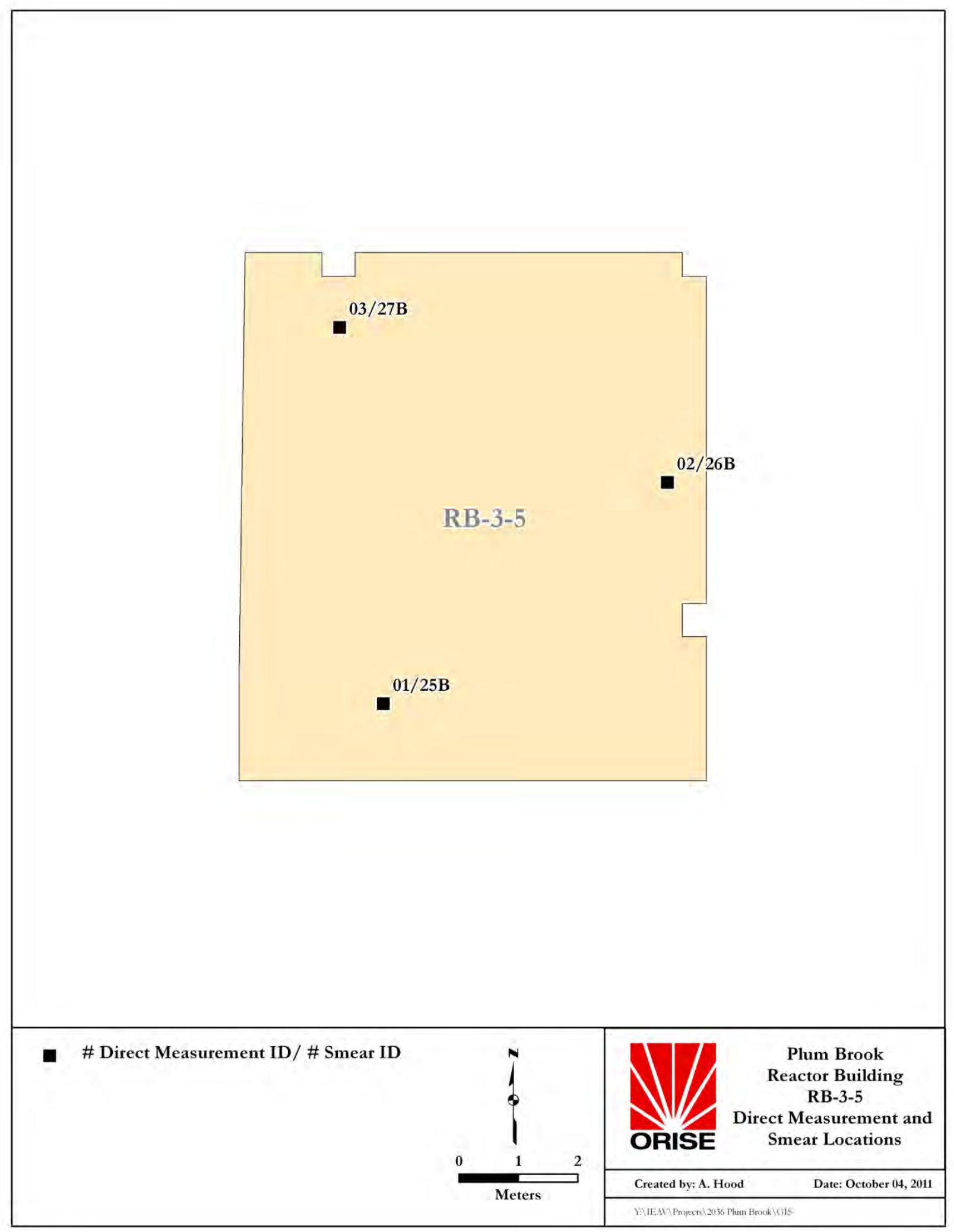

Figure A-6. RB-3-5 (-15 ft elevation)—Direct Measurement Locations 


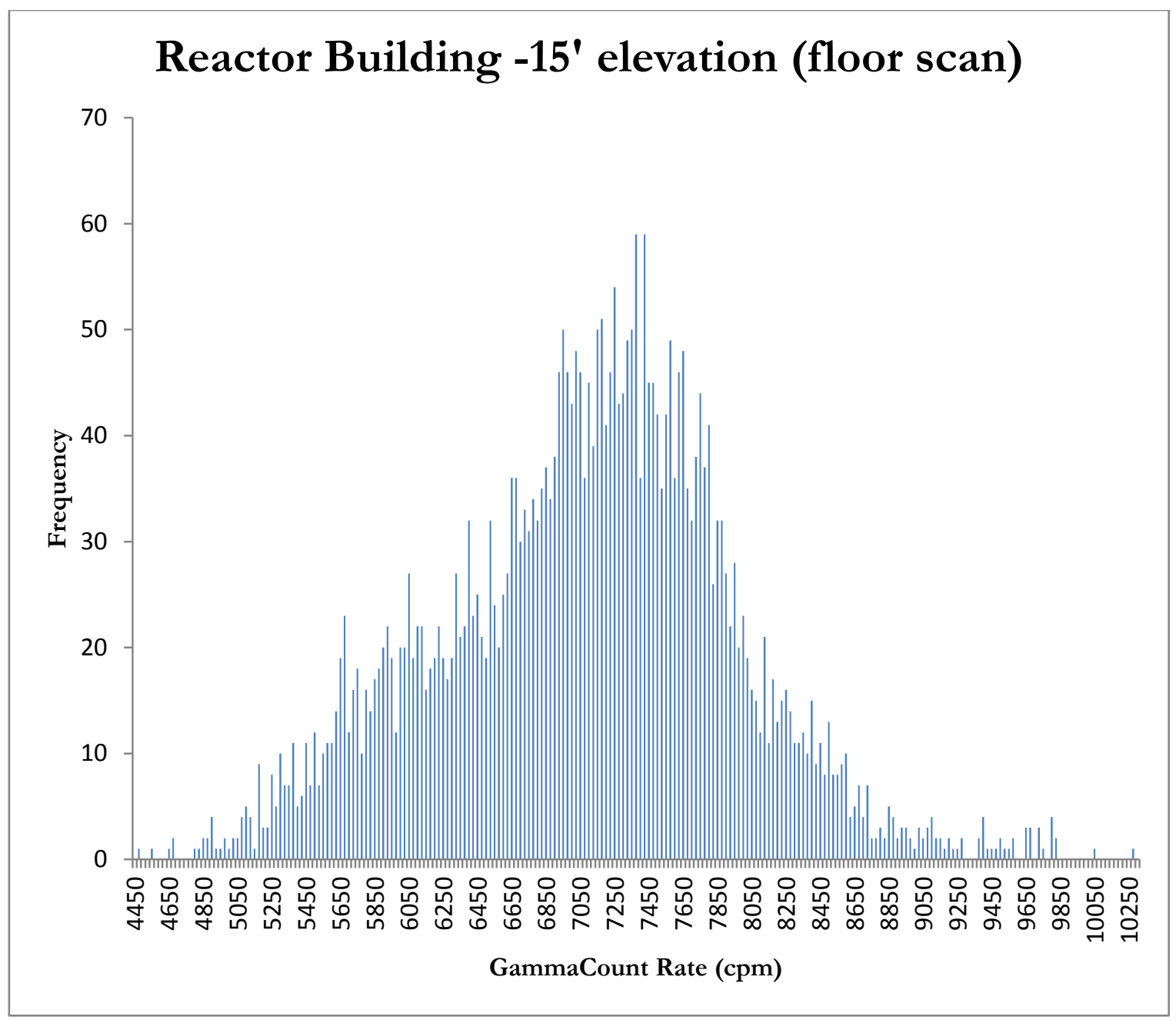

Figure A-7. Reactor Building -15 ft elevation-Gamma Scan Histogram 


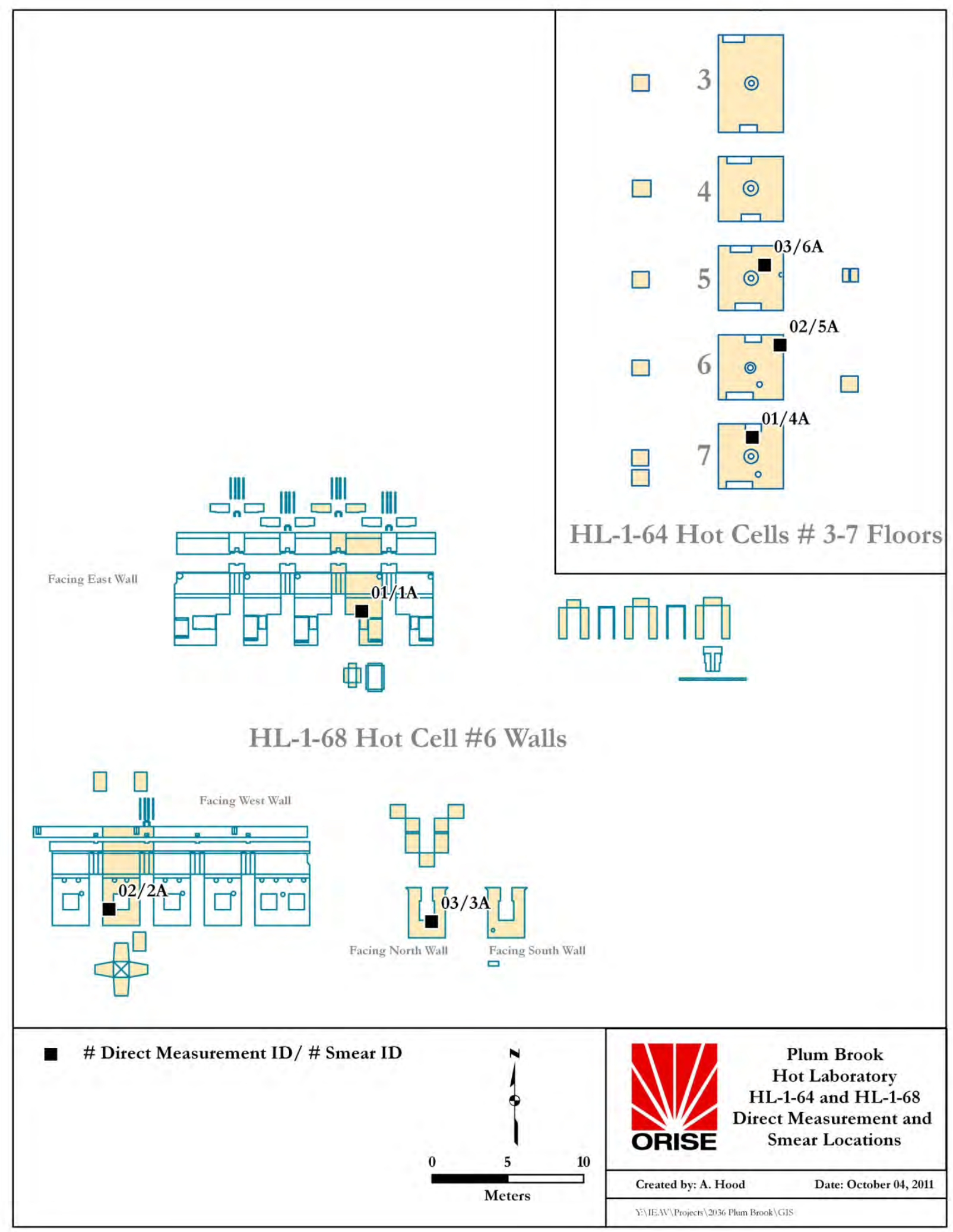

Figure A-8. HL-1-64 and HL-1-68-Direct Measurement Locations 


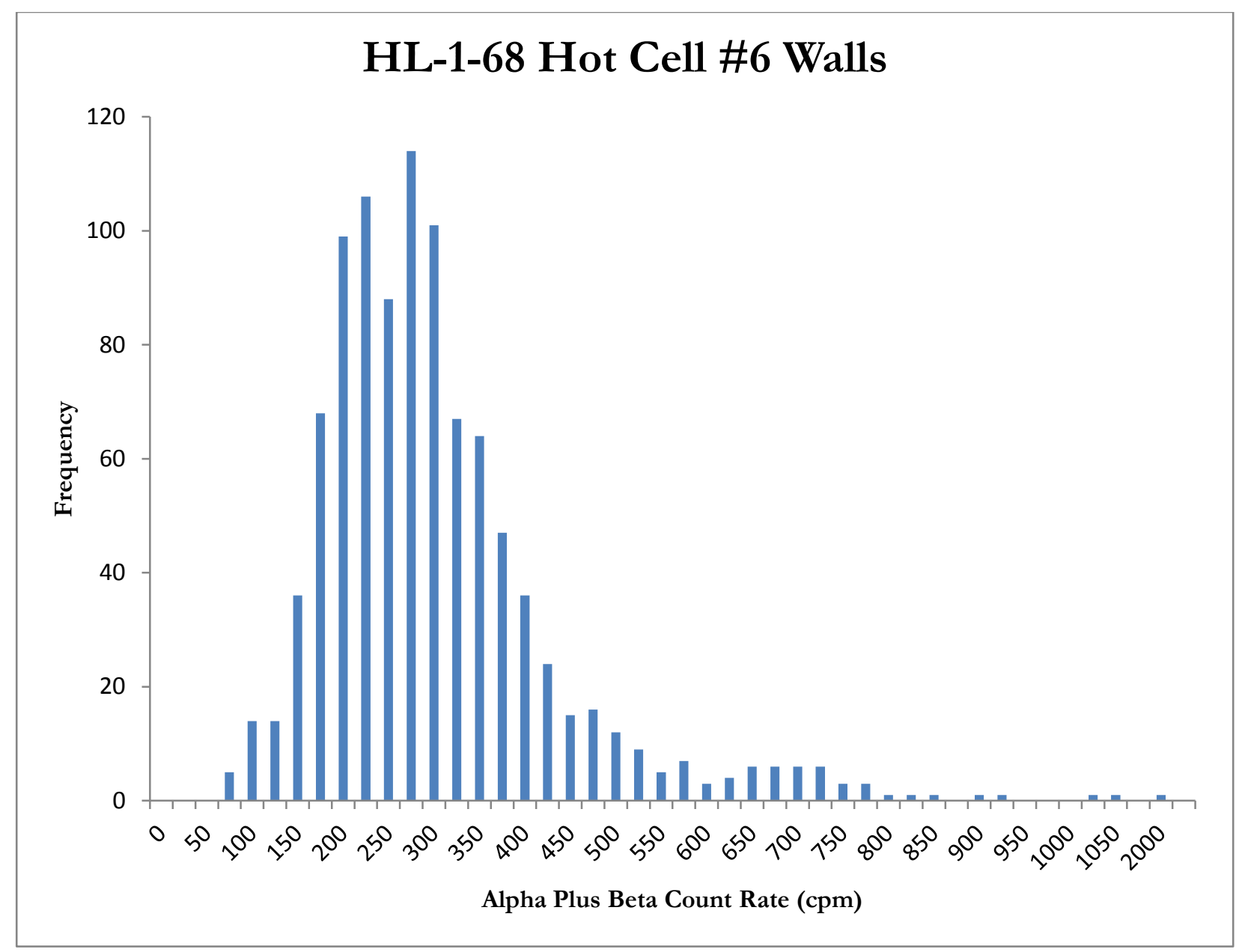

Figure A-9. HL-1-68- Alpha Plus Beta Scan Histogram 


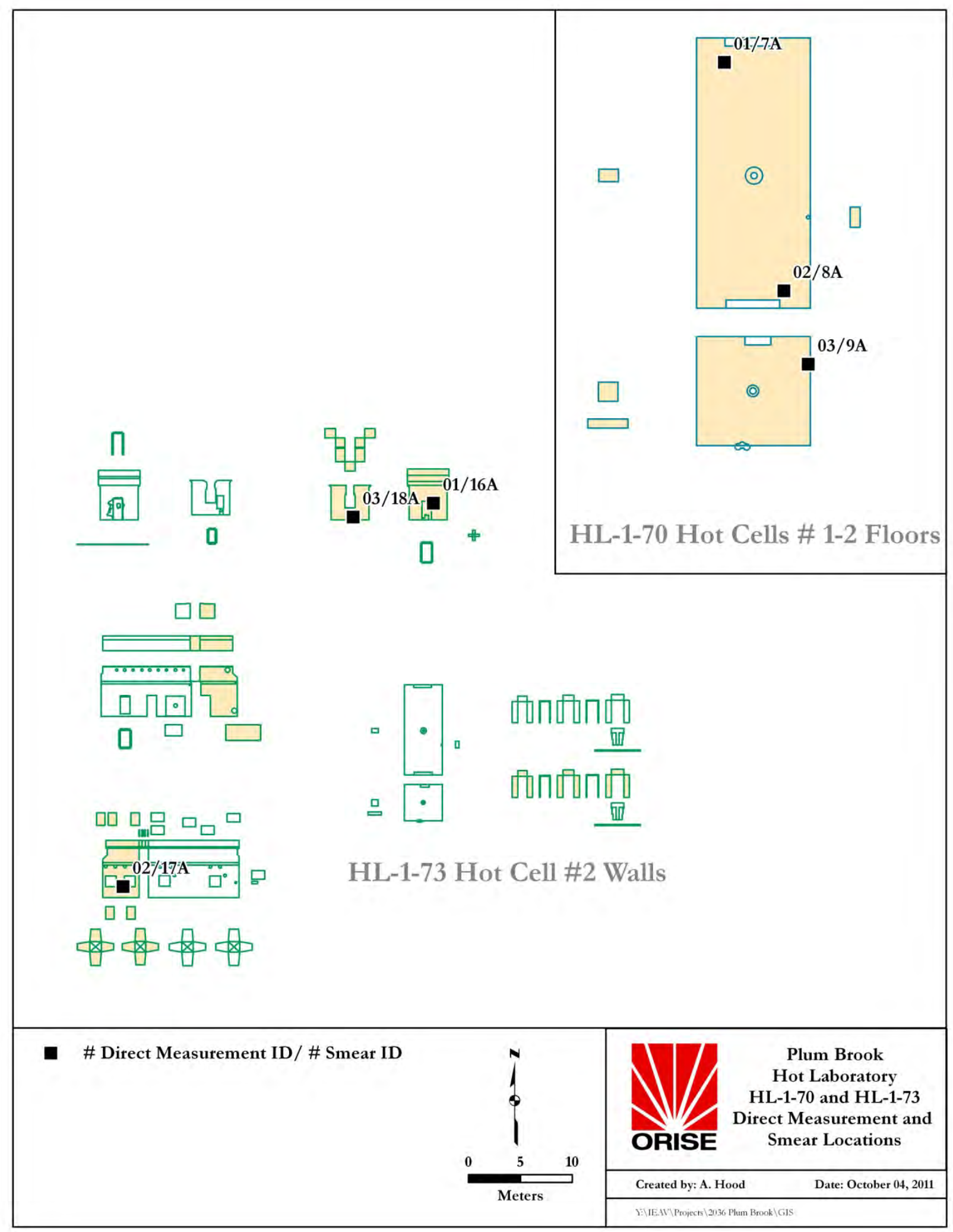

Figure A-10. HL-1-70 and HL-1-73-Direct Measurement Locations 


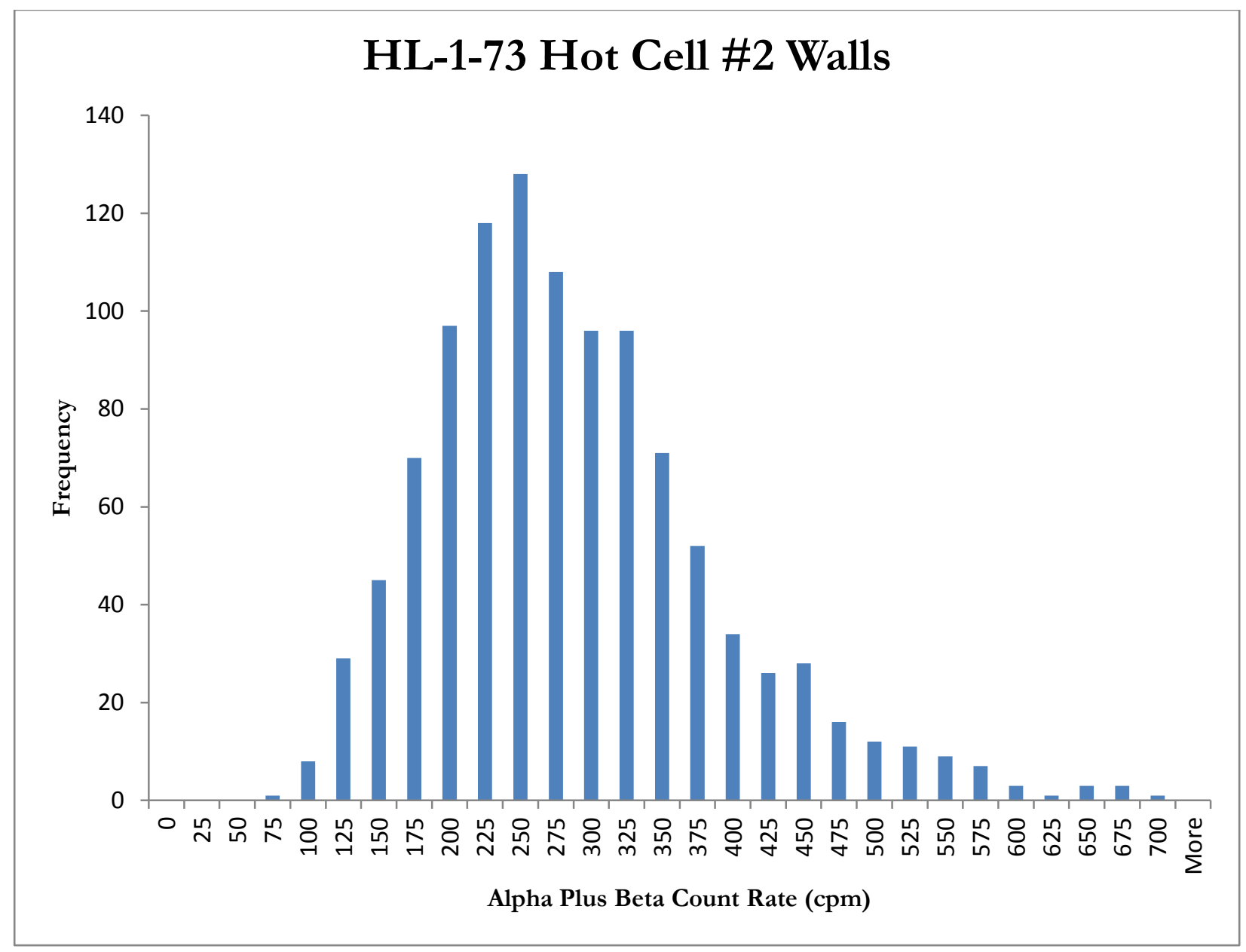

Figure A-11. HL-1-73 - Alpha Plus Beta Scan Histogram 


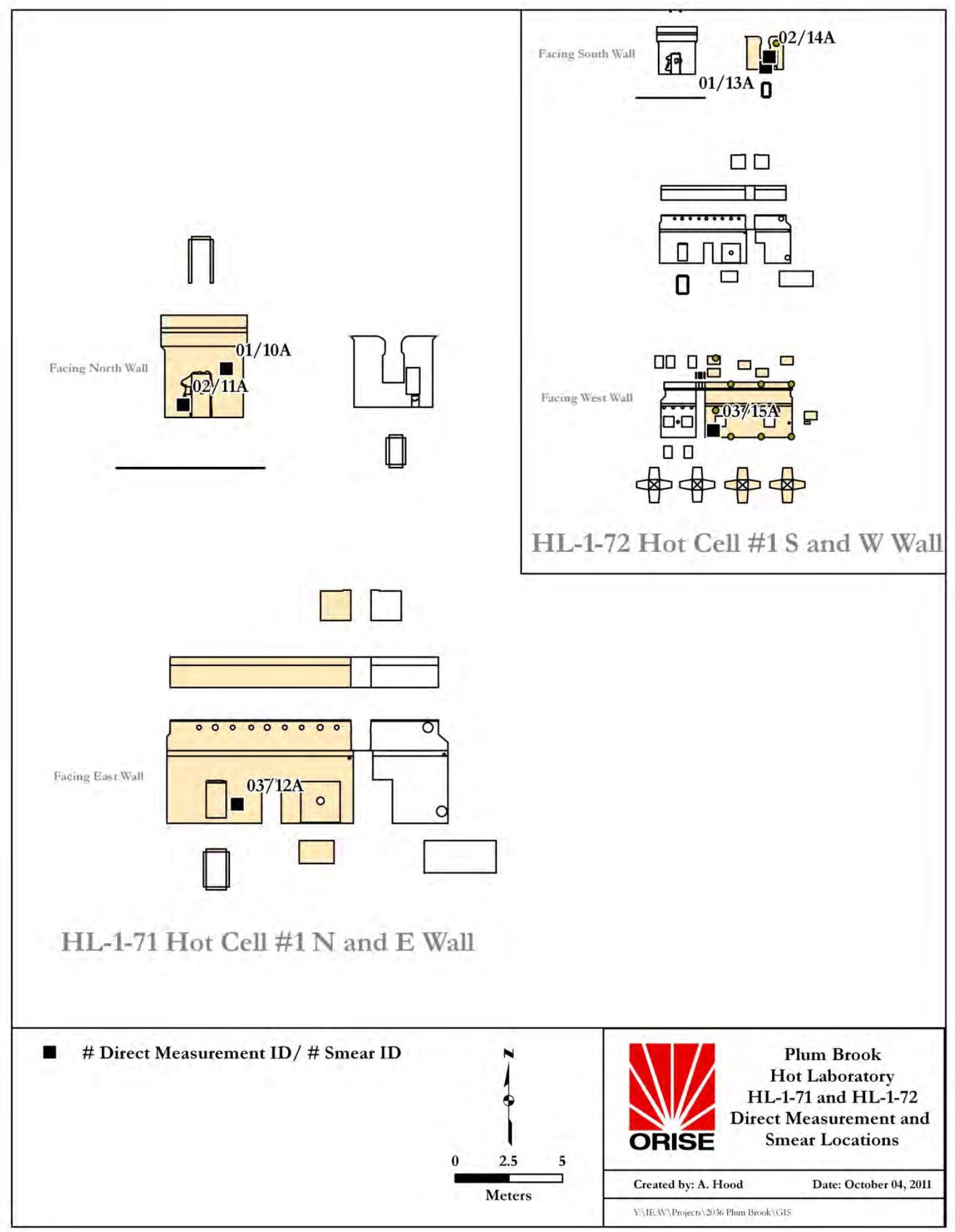

Figure A-12. HL-1-71 and HL-1-72-Direct Measurement Locations 


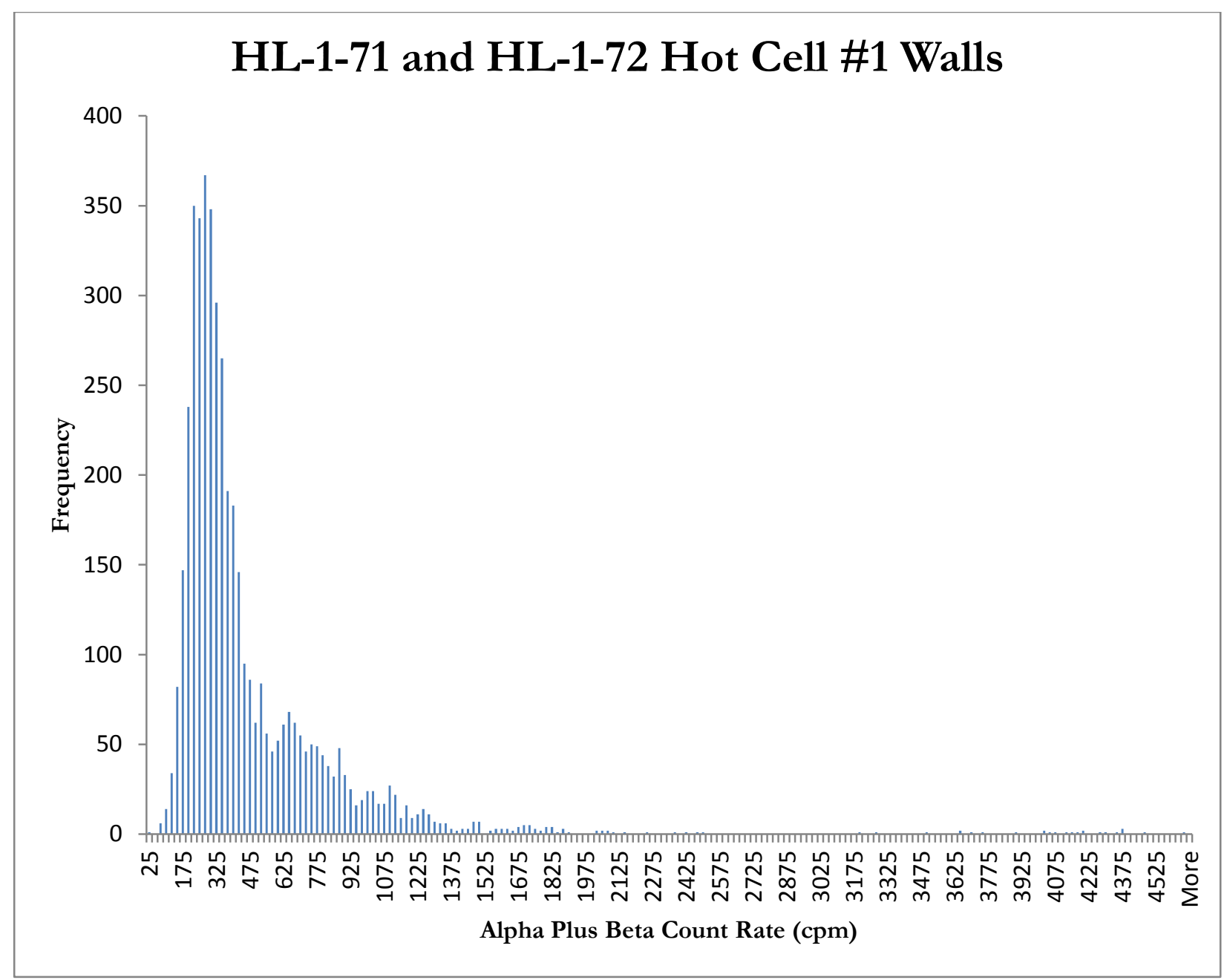

Figure A-13. HL-1-71 and HL-1-72-Alpha Plus Beta Scan Histogram 


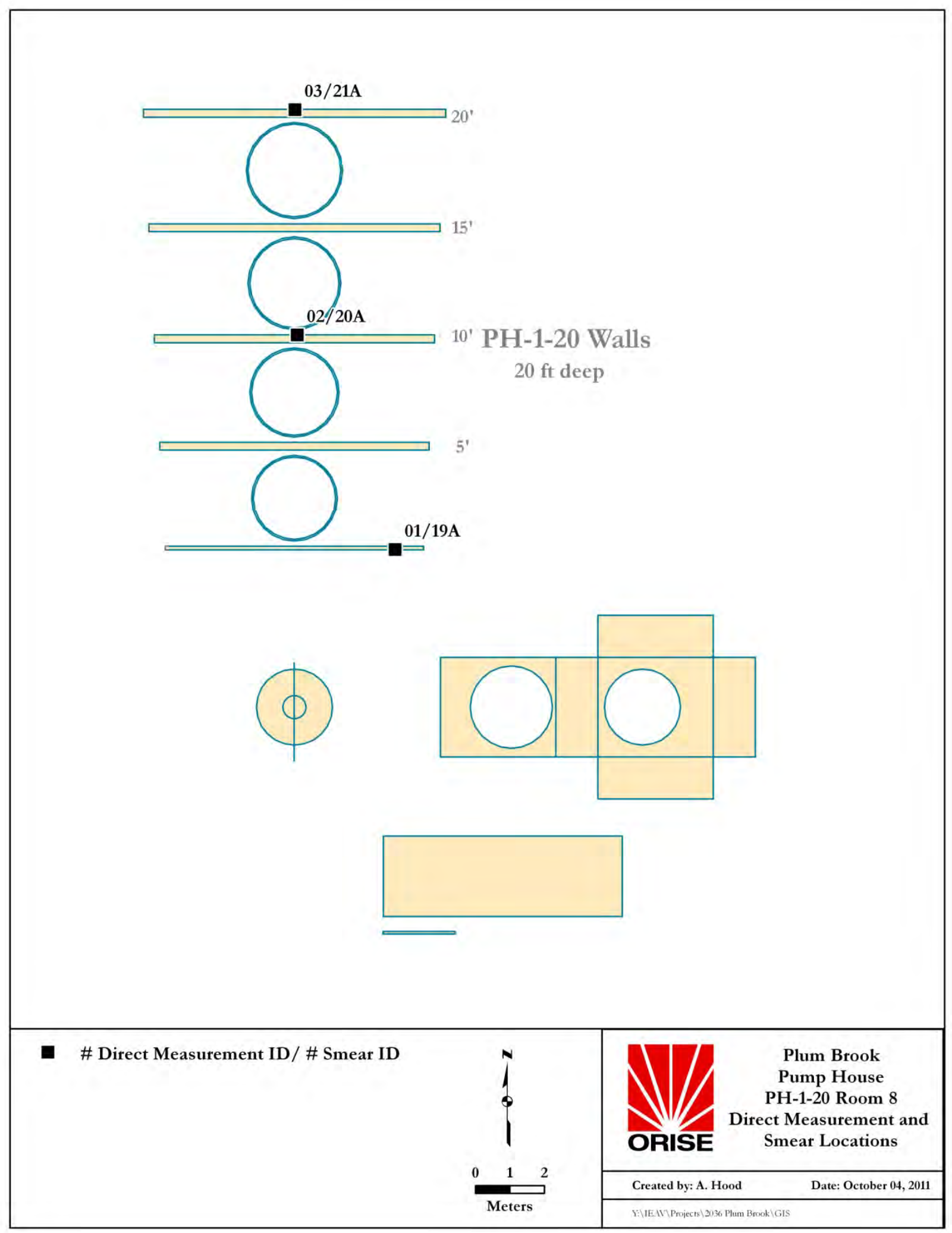

Figure A-14. PH-1-20 (Room 8)-Direct Measurement Locations 


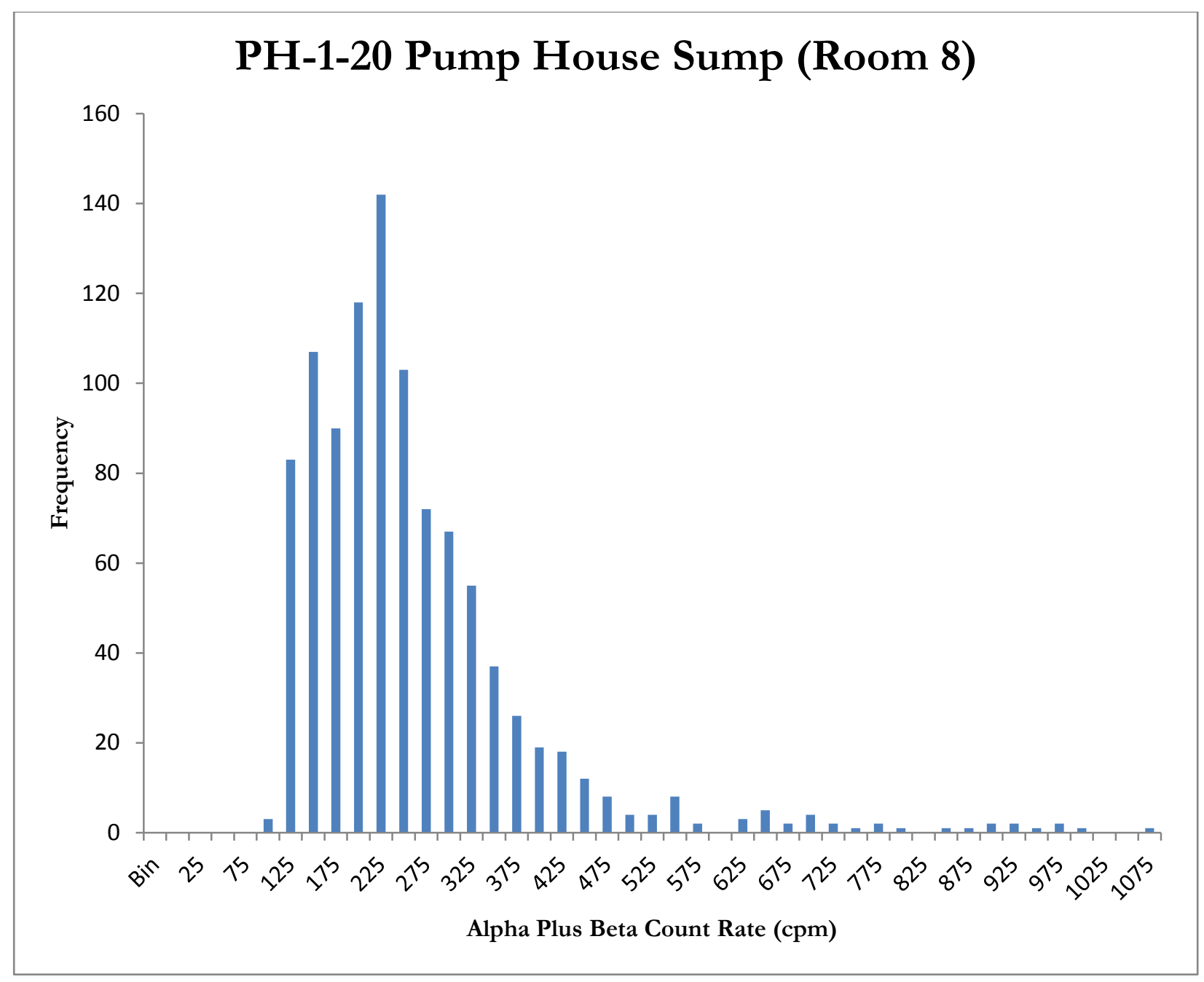

Figure A-15. PH-1-20 (Room 8)-Alpha Plus Beta Scan Histogram 


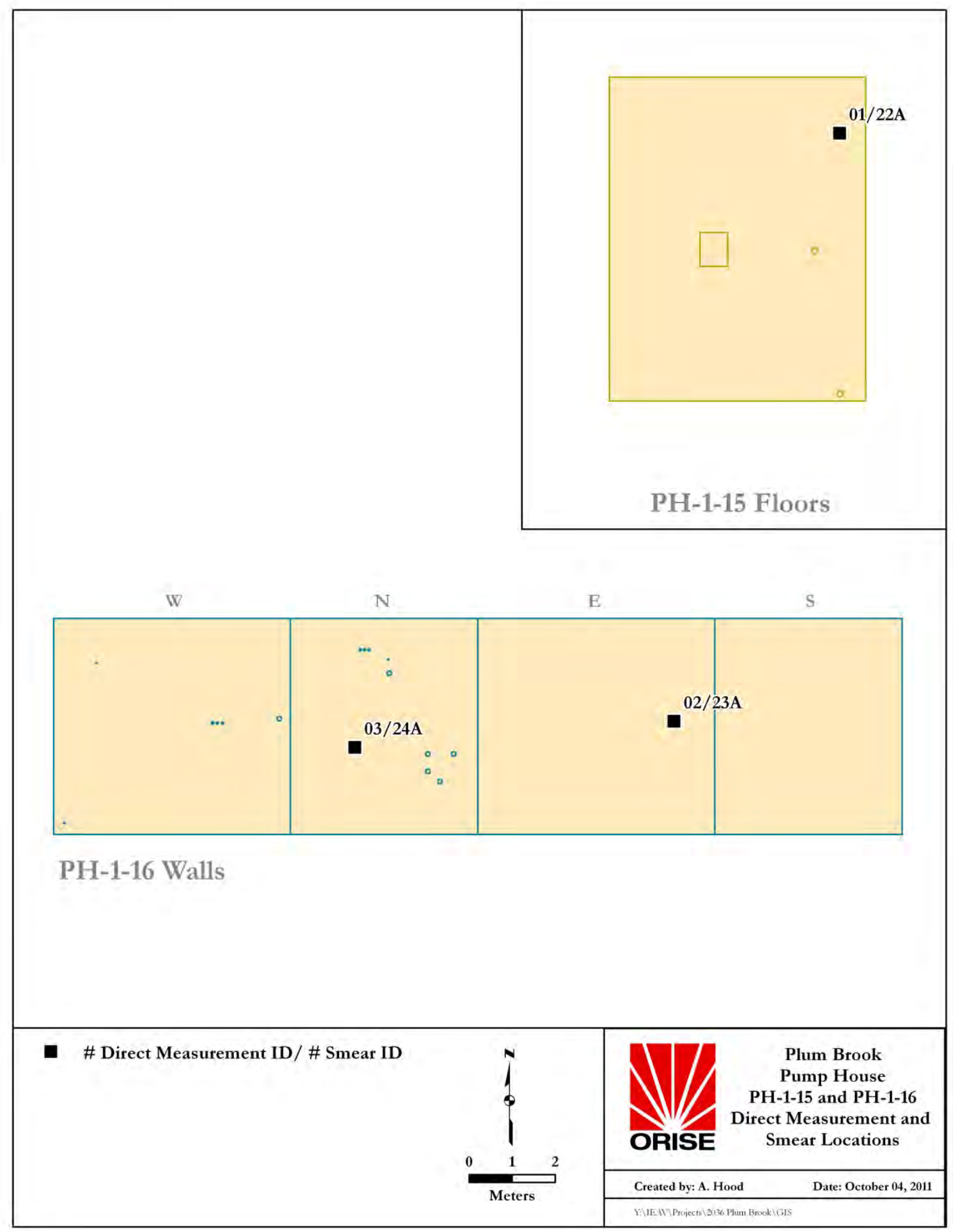

Figure A-16. PH-1-15 and PH-1-16 (Room 6)-Direct Measurement Locations 


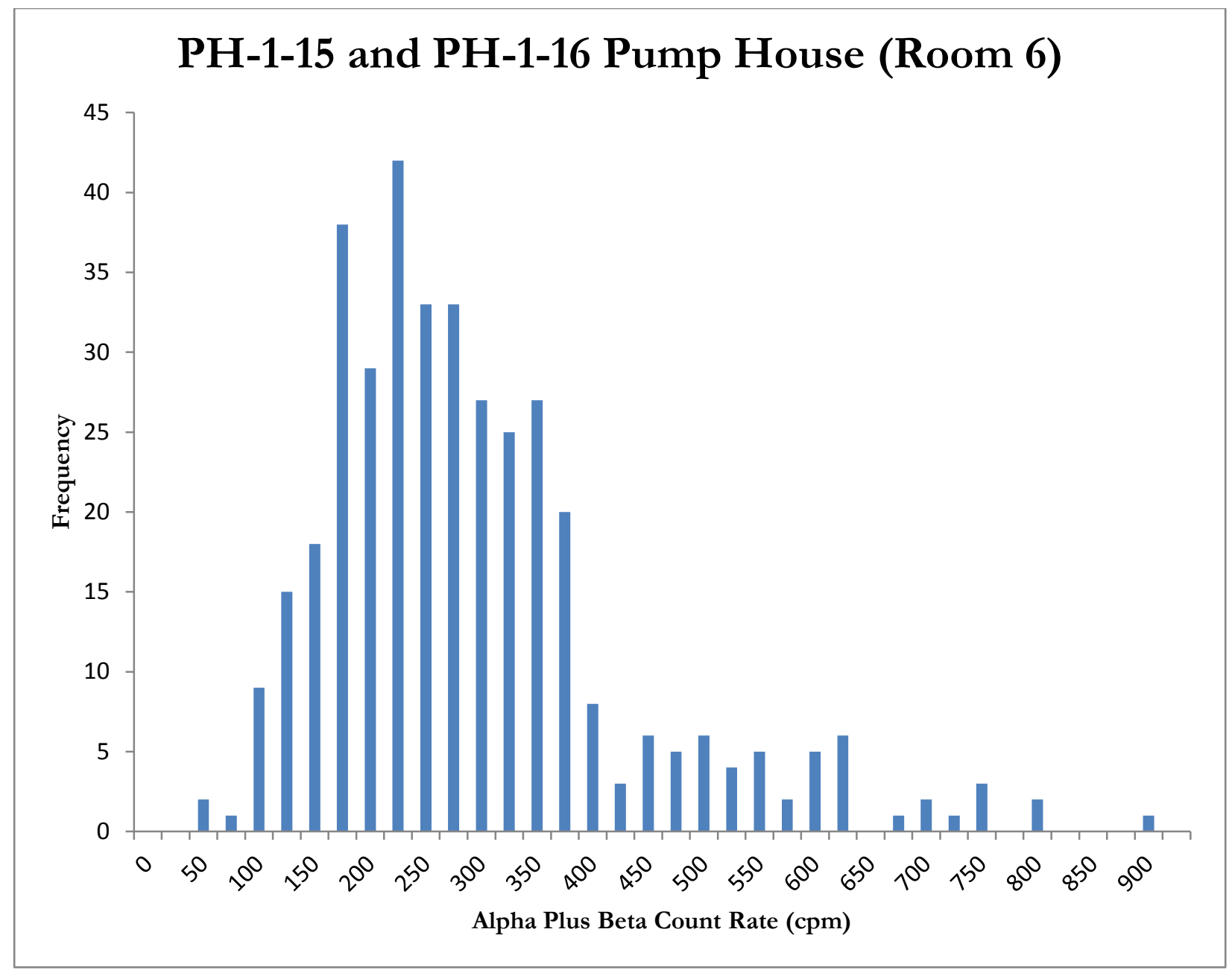

Figure A-17. PH-1-15 and PH-1-16 (Room 6)-Alpha Plus Beta Scan Histogram 


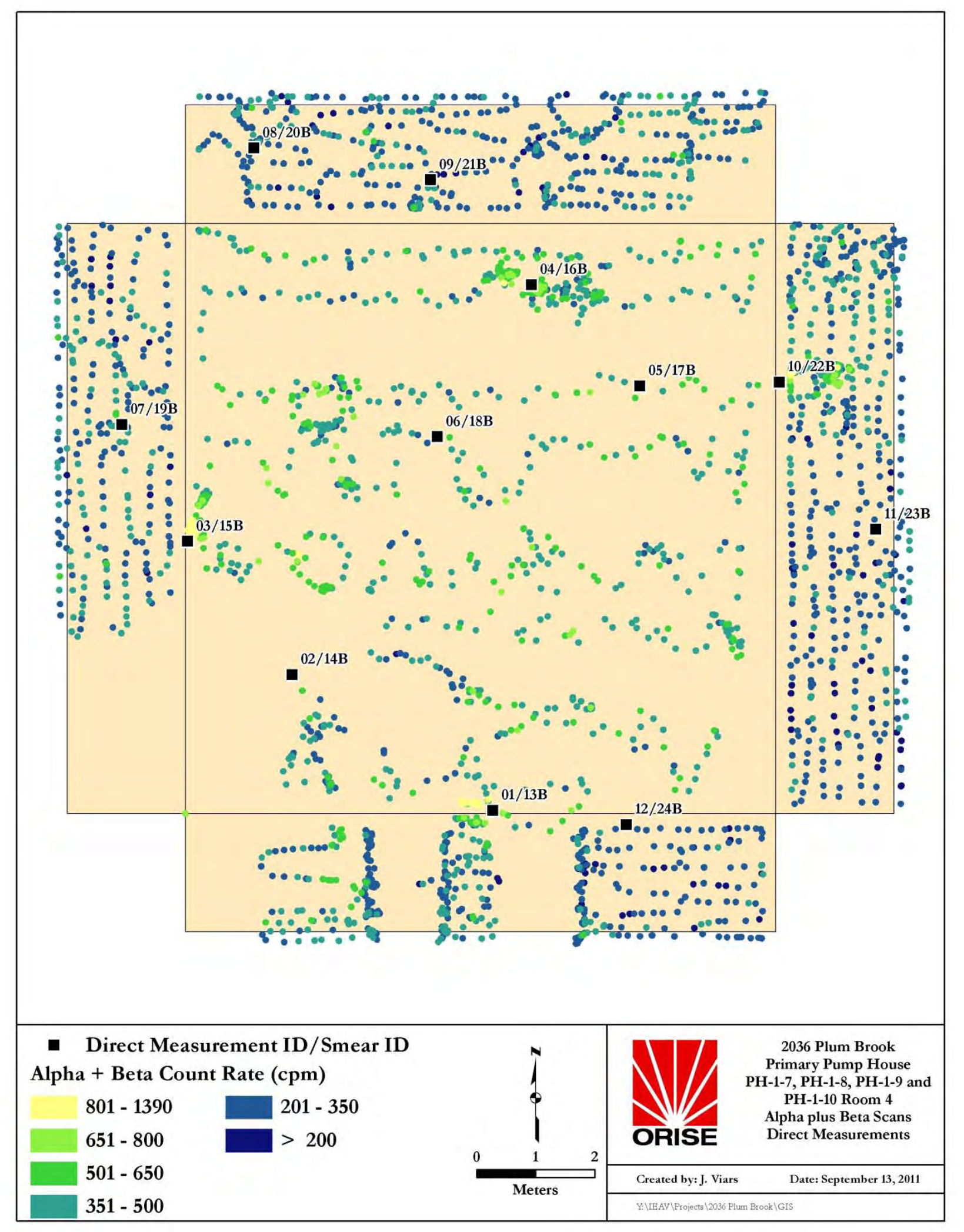

Figure A-18. Primary Pump House (Room 4)-Alpha Plus Beta Scans and Direct Measurement Locations 


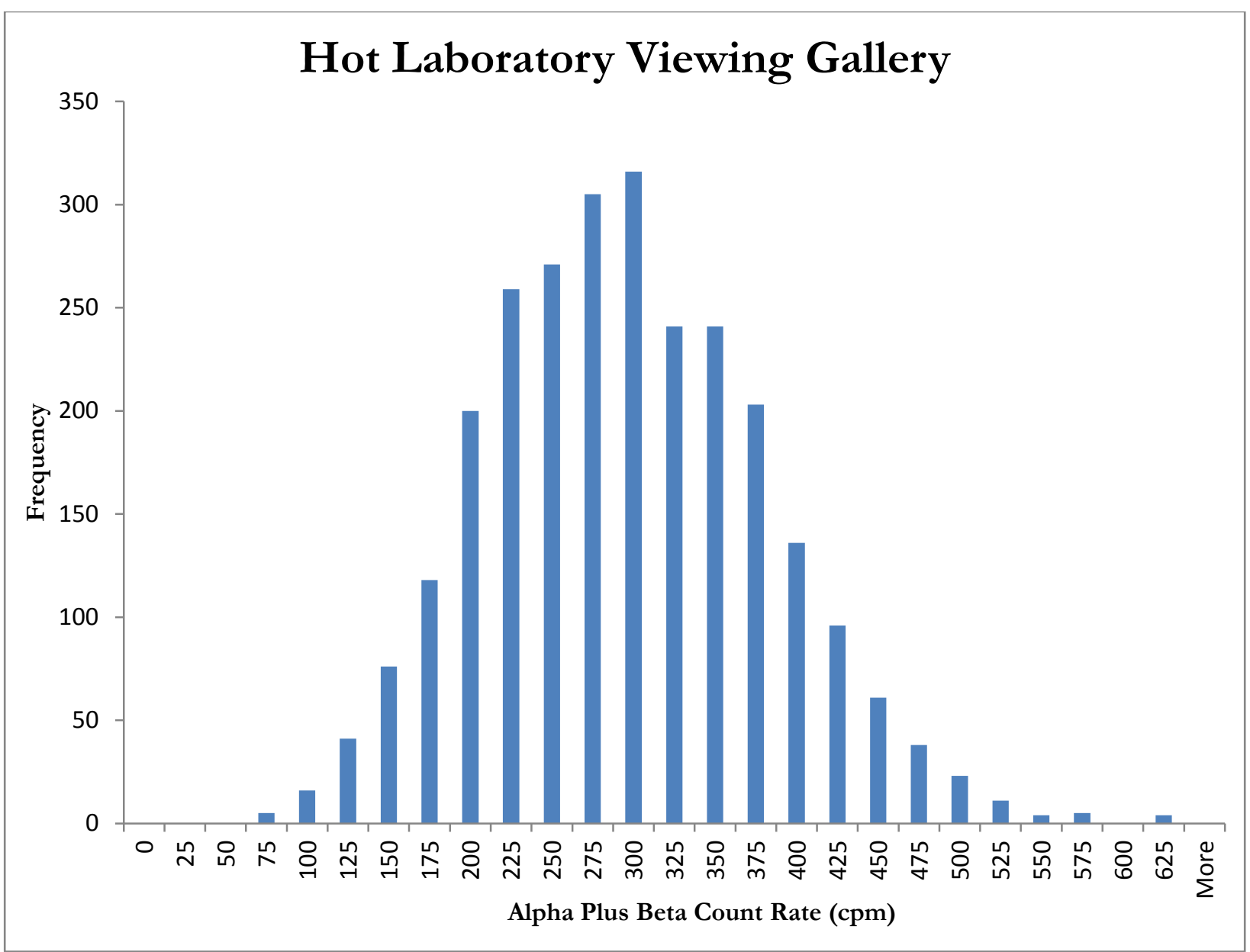

Figure A-19. Hot Laboratory Viewing Gallery-Alpha Plus Beta Scan Histogram 


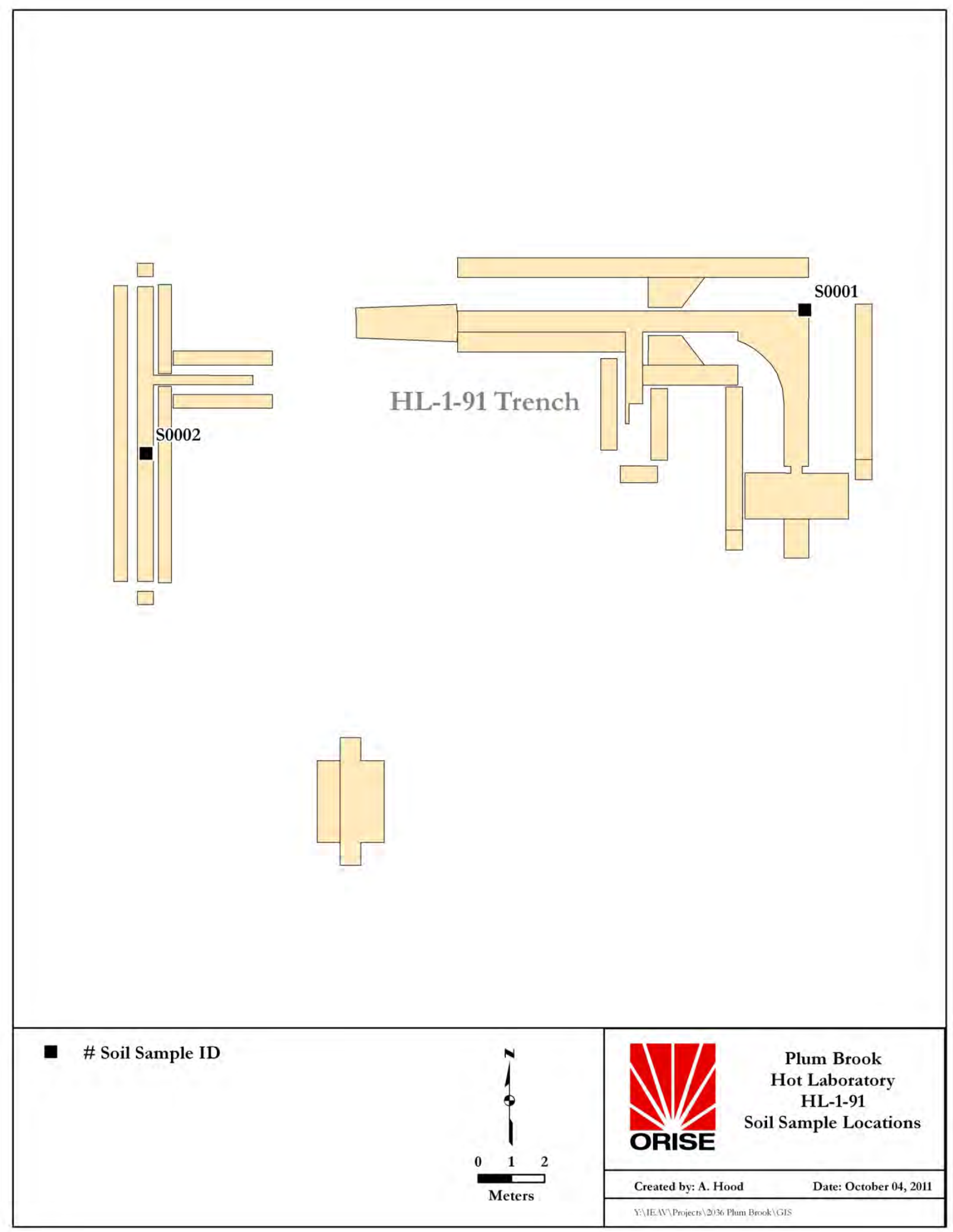

Figure A-20. HL-1-91 Trenches-Soil Sample Locations 


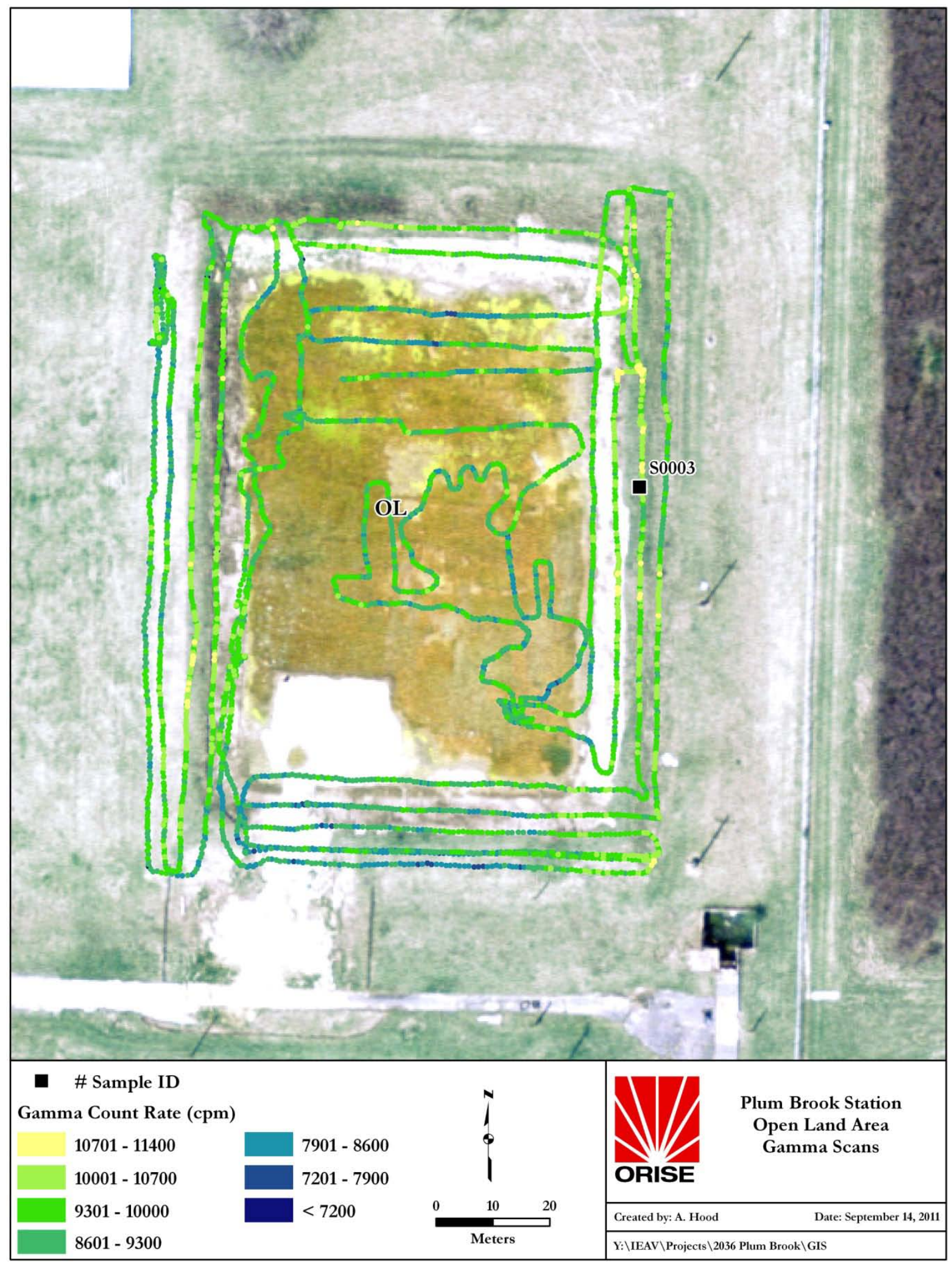

Figure A-21. Emergency Retention Basin OL-1-32-Gamma Scans and Soil Sample

\section{Locations}




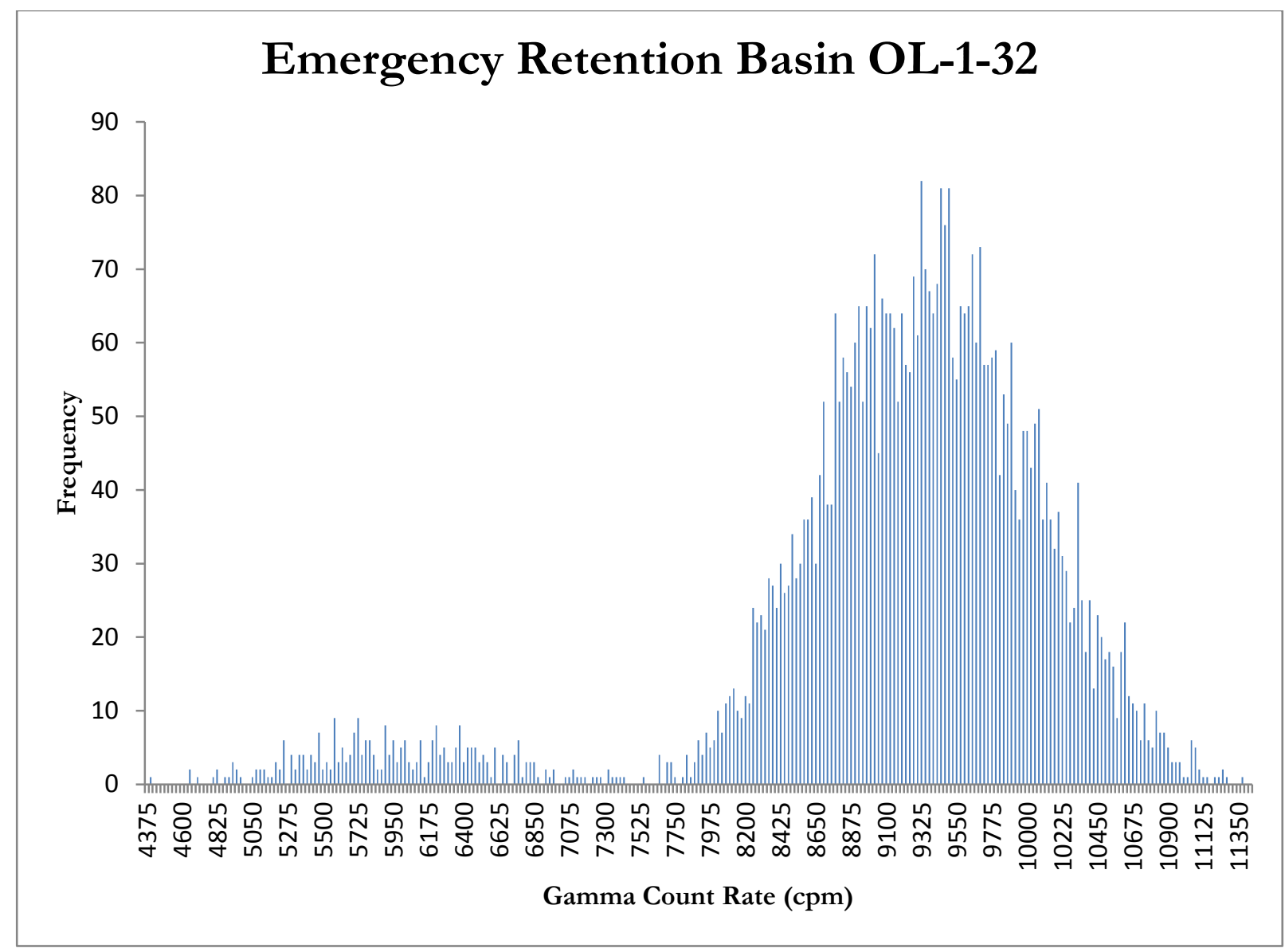

Figure A-22. Emergency Retention Basin OL-1-32-Gamma Scan Histogram 
APPENDIX B

\section{TABLES}




\begin{tabular}{|c|c|c|c|c|c|}
\hline \multicolumn{6}{|c|}{$\begin{array}{l}\text { Table B-1. Surface Activity Summary } \\
\text { Plum Brook Reactor Facility }\end{array}$} \\
\hline \multirow[b]{2}{*}{ Survey Unit } & \multirow[b]{2}{*}{$\begin{array}{c}\mathrm{DCGL}_{\mathrm{GB}} \\
(\mathrm{dpm} / 100 \\
\mathrm{cm} 2)\end{array}$} & \multirow[b]{2}{*}{$\begin{array}{l}\text { Measurement/Smear } \\
\text { ID }\end{array}$} & \multicolumn{3}{|c|}{ Activity $\left(\mathrm{dpm} / 100 \mathrm{~cm}^{2}\right)$} \\
\hline & & & $\begin{array}{c}\text { Direct } \\
\text { Measurement } \\
(\alpha+\beta)\end{array}$ & $\begin{array}{l}\text { Removable } \\
(\alpha)\end{array}$ & $\begin{array}{l}\text { Removable } \\
(\beta)\end{array}$ \\
\hline \multicolumn{6}{|l|}{$\begin{array}{l}\text { Reactor } \\
\text { Building }\end{array}$} \\
\hline CV-3-33 & 18,228 & $01 / \mathrm{n} / \mathrm{a}$ & 4,314 & $\mathrm{n} / \mathrm{a}$ & $\mathrm{n} / \mathrm{a}$ \\
\hline CV-3-45 & 11,567 & $02 / \mathrm{n} / \mathrm{a}$ & 5,417 & $\mathrm{n} / \mathrm{a}$ & $\mathrm{n} / \mathrm{a}$ \\
\hline \multirow[t]{3}{*}{$\mathrm{CV}-3-43$} & 11,567 & $01 / 1 \mathrm{~B}$ & 1,233 & 0 & 2 \\
\hline & & $02 / 2 B$ & 810 & 2 & 2 \\
\hline & & $03 / 3 \mathrm{~B}$ & 1,137 & 0 & -4 \\
\hline \multirow[t]{3}{*}{$\mathrm{CV}-3-44$} & 11,567 & $04 / 4 \mathrm{~B}$ & 1,004 & 0 & 3 \\
\hline & & $05 / 5 \mathrm{~B}$ & 1,191 & 0 & 3 \\
\hline & & $06 / 6 \mathrm{~B}$ & 1,820 & 2 & -3 \\
\hline \multirow[t]{3}{*}{$\mathrm{CV}-3-42$} & 11,567 & 07/7B & 1,905 & 0 & 3 \\
\hline & & $08 / 8 \mathrm{~B}$ & 1,481 & 0 & -2 \\
\hline & & 09/9B & 1,463 & 2 & 2 \\
\hline \multirow[t]{3}{*}{ CV-3-41 } & 11,567 & 10/10B & 1,208 & 4 & -1 \\
\hline & & 11/11B & 1,219 & 0 & -5 \\
\hline & & $12 / 12 \mathrm{~B}$ & 1,761 & 0 & -4 \\
\hline \multirow[t]{2}{*}{$\mathrm{CV}-3-5$} & 9,482 & $01 / \mathrm{n} / \mathrm{a}$ & 1,244 & $\mathrm{n} / \mathrm{a}$ & $\mathrm{n} / \mathrm{a}$ \\
\hline & & $02 / \mathrm{n} / \mathrm{a}$ & 2,206 & $\mathrm{n} / \mathrm{a}$ & $\mathrm{n} / \mathrm{a}$ \\
\hline CV-3-4 & 9,482 & $03 / \mathrm{n} / \mathrm{a}$ & 552 & $\mathrm{n} / \mathrm{a}$ & $\mathrm{n} / \mathrm{a}$ \\
\hline \multirow[t]{3}{*}{ RB-4-30 } & 12,556 & $01 / 28 \mathrm{~B}$ & 4,016 & 0 & 4 \\
\hline & & $02 / 29 B$ & 1,528 & 0 & 3 \\
\hline & & 03/30B & 1,838 & 4 & 1 \\
\hline \multirow[t]{3}{*}{ RB-4-21 } & 12,556 & 04/31B & 4,622 & 2 & 3 \\
\hline & & $05 / 32 \mathrm{~B}$ & 1,628 & 2 & 1 \\
\hline & & 06/33B & 1,585 & 0 & 1 \\
\hline \multirow[t]{3}{*}{ RB-3-5 } & 30,355 & $01 / 25 \mathrm{~B}$ & 1,880 & 0 & 3 \\
\hline & & $02 / 26 \mathrm{~B}$ & 1,813 & 2 & -2 \\
\hline & & 03/27B & 1,958 & 0 & -3 \\
\hline \multicolumn{6}{|l|}{$\begin{array}{c}\text { Hot } \\
\text { Laboratory }\end{array}$} \\
\hline \multirow[t]{3}{*}{ HL-1-68 } & 30,960 & $01 / 1 \mathrm{~A}$ & 4,117 & 2 & -3 \\
\hline & & $02 / 2 \mathrm{~A}$ & 1,980 & 0 & -2 \\
\hline & & $03 / 3 \mathrm{~A}$ & 2,188 & 2 & 1 \\
\hline HL-1-64 & 30,960 & $01 / 4 \mathrm{~A}$ & 6,913 & 0 & -2 \\
\hline
\end{tabular}




\begin{tabular}{|c|c|c|c|c|c|}
\hline \multicolumn{6}{|c|}{$\begin{array}{l}\text { Table B-1. Surface Activity Summary } \\
\text { Plum Brook Reactor Facility }\end{array}$} \\
\hline \multirow[b]{2}{*}{ Survey Unit } & \multirow{2}{*}{$\begin{array}{c}\text { DCGL }_{G B} \\
(\mathrm{dpm} / 100 \\
\mathrm{cm} 2)\end{array}$} & \multirow[b]{2}{*}{$\begin{array}{l}\text { Measurement/Smear } \\
\text { ID }\end{array}$} & \multicolumn{3}{|c|}{ Activity $\left(\mathrm{dpm} / 100 \mathrm{~cm}^{2}\right)$} \\
\hline & & & $\begin{array}{c}\text { Direct } \\
\text { Measurement } \\
(\alpha+\beta)\end{array}$ & $\begin{array}{l}\text { Removable } \\
(\alpha)\end{array}$ & $\begin{array}{c}\text { Removable } \\
(\beta)\end{array}$ \\
\hline \multicolumn{6}{|l|}{$\begin{array}{l}\text { Reactor } \\
\text { Building }\end{array}$} \\
\hline & & $02 / 5 \mathrm{~A}$ & 2,847 & 0 & -2 \\
\hline & & $03 / 6 \mathrm{~A}$ & 1,885 & 0 & -1 \\
\hline \multirow[t]{3}{*}{ HL-1-70 } & 30,960 & $01 / 7 \mathrm{~A}$ & 3,947 & 0 & -3 \\
\hline & & $02 / 8 \mathrm{~A}$ & 10,935 & 2 & -2 \\
\hline & & 03/9A & 1,478 & 0 & -4 \\
\hline \multirow[t]{3}{*}{ HL-1-71 } & 30,960 & 01/10A & 7,378 & 2 & -5 \\
\hline & & $02 / 11 \mathrm{~A}$ & 3,900 & 2 & 2 \\
\hline & & $03 / 12 \mathrm{~A}$ & 6,461 & 0 & -4 \\
\hline \multirow[t]{3}{*}{ HL-1-72 } & 30,960 & $01 / 13 \mathrm{~A}$ & 10,259 & 0 & 2 \\
\hline & & $02 / 14 \mathrm{~A}$ & 15,334 & 0 & 2 \\
\hline & & $03 / 15 \mathrm{~A}$ & 4,307 & 2 & 1 \\
\hline \multirow[t]{3}{*}{ HL-1-73 } & 30,960 & $01 / 16 \mathrm{~A}$ & 1,556 & 4 & -2 \\
\hline & & $02 / 17 \mathrm{~A}$ & 1,223 & 0 & -3 \\
\hline & & 03/18A & 1,114 & 4 & -2 \\
\hline \multicolumn{6}{|c|}{ Primary Pump House } \\
\hline PH-1-20 & 23,713 & 01/19A & 4,007 & 2 & 1 \\
\hline \multirow[t]{2}{*}{ Room 8} & & $02 / 20 \mathrm{~A}$ & 2,679 & 6 & 3 \\
\hline & & $03 / 21 \mathrm{~A}$ & 1,037 & 0 & 1 \\
\hline PH-1-15 & 23,713 & $01 / 22 \mathrm{~A}$ & 10,681 & 2 & -1 \\
\hline PH-1-16 & & $02 / 23 \mathrm{~A}$ & 1,542 & 0 & -3 \\
\hline Room 6 & & $03 / 24 \mathrm{~A}$ & 750 & 4 & 1 \\
\hline PH-1-7 & 10,067 & $01 / 13 \mathrm{~B}$ & 3,020 & 0 & 1 \\
\hline \multirow[t]{2}{*}{ Room 4} & & $02 / 14 \mathrm{~B}$ & 2,021 & 2 & 4 \\
\hline & & 03/15B & 3,280 & 0 & -2 \\
\hline PH-1-8 & 10,067 & $04 / 16 \mathrm{~B}$ & 1,825 & 0 & 1 \\
\hline \multirow[t]{2}{*}{ Room 4} & & 05/17B & 1,660 & 0 & 1 \\
\hline & & 06/18B & 1,769 & 0 & 3 \\
\hline PH-1-9 & 10,067 & $07 / 19 \mathrm{~B}$ & 1,604 & 0 & 1 \\
\hline \multirow[t]{2}{*}{ Room 4} & & 08/20B & 1,351 & 0 & -2 \\
\hline & & $09 / 21 \mathrm{~B}$ & 1,540 & 0 & 4 \\
\hline PH-1-10 & 10,067 & $10 / 22 B$ & 2,911 & 0 & 2 \\
\hline
\end{tabular}




\begin{tabular}{|c|c|c|c|c|c|}
\hline \multicolumn{6}{|c|}{$\begin{array}{l}\text { Table B-1. Surface Activity Summary } \\
\text { Plum Brook Reactor Facility }\end{array}$} \\
\hline \multirow[b]{2}{*}{ Survey Unit } & \multirow{2}{*}{$\begin{array}{c}\text { DCGL }_{G B} \\
(\mathrm{dpm} / 100 \\
\mathrm{cm} 2)\end{array}$} & \multirow[b]{2}{*}{$\begin{array}{l}\text { Measurement/Smear } \\
\text { ID }\end{array}$} & \multicolumn{3}{|c|}{ Activity $\left(\mathrm{dpm} / 100 \mathrm{~cm}^{2}\right)$} \\
\hline & & & $\begin{array}{c}\text { Direct } \\
\text { Measurement } \\
(\alpha+\beta)\end{array}$ & $\begin{array}{l}\text { Removable } \\
(\alpha)\end{array}$ & $\begin{array}{c}\text { Removable } \\
(\beta)\end{array}$ \\
\hline \multicolumn{6}{|l|}{$\begin{array}{l}\text { Reactor } \\
\text { Building }\end{array}$} \\
\hline \multirow[t]{2}{*}{ Room 4} & & $11 / 23 \mathrm{~B}$ & 1,436 & 0 & -2 \\
\hline & & $12 / 24 \mathrm{~B}$ & 1,311 & 2 & 2 \\
\hline
\end{tabular}




\begin{tabular}{|c|c|c|c|c|c|c|c|c|c|c|}
\hline \multicolumn{11}{|c|}{$\begin{array}{c}\text { Table B-2. } \\
\text { Radionuclide Concentrations in Soil Samples } \\
\text { Plum Brook Reactor Facility }\end{array}$} \\
\hline $\begin{array}{c}\text { ORISE } \\
\text { Sample ID }\end{array}$ & \multicolumn{3}{|c|}{ Cs-137 } & \multicolumn{3}{|c|}{ Co-60 } & \multicolumn{3}{|c|}{ Sr-90 } & Sum of Fractions \\
\hline S0001 & 1.38 & \pm & $0.11^{\mathrm{b}}$ & 0.21 & \pm & 0.04 & 0.44 & \pm & 0.48 & 0.23 \\
\hline S0002 & 1.01 & \pm & 0.11 & -0.02 & \pm & 0.06 & 0.29 & \pm & 0.48 & 0.12 \\
\hline S0003 & -0.04 & \pm & 0.04 & 0.01 & \pm & 0.04 & \multicolumn{3}{|c|}{$\mathrm{n} / \mathrm{a}^{\mathrm{c}}$} & 0.003 \\
\hline S0004 & 0.02 & \pm & 0.02 & -0.03 & \pm & 0.05 & \multicolumn{3}{|c|}{$\mathrm{n} / \mathrm{a}$} & 0.002 \\
\hline $\mathrm{S} 0005^{\mathrm{d}}$ & 4.62 & \pm & 0.37 & 0.06 & \pm & 0.05 & 0.57 & \pm & 0.47 & 0.44 \\
\hline
\end{tabular}

aRefer to Figures A-20 and A-21 for sample locations S0001 to S0003. S0004 was collected from the $-15 \mathrm{ft}$. elevation of the Reactor Building where mud was seeping from outside into the sump area.

bUncertainties represent the $95 \%$ confidence level, based on total propagated uncertainties (TPUs). cAnalysis not performed.

dLicensee sample ID SR-277-3 collected from SU OL-1-27 given to ORISE for laboratory comparison analysis. The licensee reported Cs-137 and Co-60 results of $4.29 \mathrm{pCi} / \mathrm{g}$ and $<\mathrm{MDA}$, respectively. 
APPENDIX C

MAJOR INSTRUMENTATION

Plum Brook Reactor Facility

2036-SR-01-0 
The display of a specific product is not to be construed as an endorsement of the product or its manufacturer by the author or ORAU.

\section{C.1 SCANNING AND MEASUREMENT INSTRUMENT/DETECTOR COMBINATIONS}

\section{C.1.1 GAMMA}

Ludlum NaI Scintillation Detector Model 44-10, Crystal: $5.1 \mathrm{~cm}$ x $5.1 \mathrm{~cm}$

(Ludlum Measurements, Inc., Sweetwater, TX)

coupled to:

Ludlum Ratemeter-scaler Model 2221

(Ludlum Measurements, Inc., Sweetwater, TX)

coupled to:

Trimble GeoXH Receiver and Data Logger (Trimble Navigation Limited, Sunnyvale, CA)

\section{C.1.2 ALPHA PLUS BETA}

Ludlum Gas Proportional Detector Model 43-68, 126 $\mathrm{cm}^{2}$ physical area

coupled to:

Ludlum Ratemeter-scaler Model 2221

(Ludlum Measurements, Inc., Sweetwater, TX)

coupled to:

Trimble GeoXH Receiver and Data Logger (Trimble Navigation Limited, Sunnyvale, CA)

Ludlum Gas Proportional Detector Model 43-68, 126 $\mathrm{cm}^{2}$ physical area

coupled to:

Ludlum Ratemeter-scaler Model 2221

(Ludlum Measurements, Inc., Sweetwater, TX)

coupled to:

Trimble S3 Total Station with TSC2 controller (Trimble Navigation Limited, Sunnyvale, CA)

\section{C.2 LABORATORY ANALYTICAL INSTRUMENTATION}

High-Purity, Extended Range Intrinsic Detector

CANBERRA/Tennelec Model No: ERVDS30-25195

(Canberra, Meriden, CT)

Used in conjunction with:

Lead Shield Model G-11

(Nuclear Lead, Oak Ridge, TN) and

Multichannel Analyzer

Canberra's Apex Gamma Software

Dell Workstation

(Canberra, Meriden, CT) 
High-Purity, Extended Range Intrinsic Detector Model No. GMX-45200-5

(AMETEK/ORTEC, Oak Ridge, TN)

used in conjunction with:

Lead Shield Model SPG-16-K8

(Nuclear Data)

Multichannel Analyzer

Canberra's Apex Gamma Software

Dell Workstation

(Canberra, Meriden, CT)

High-Purity Germanium Detector

Model GMX-30-P4, 30\% Eff.

(AMETEK/ORTEC, Oak Ridge, TN)

Used in conjunction with:

Lead Shield Model G-16

(Gamma Products, Palos Hills, IL) and

Multichannel Analyzer

Canberra's Apex Gamma Software

Dell Workstation

(Canberra, Meriden, CT)

Low-Background Gas Proportional Counter

Model LB-5100-W

(Tennelec/Canberra, Meriden, CT) 
APPENDIX D

SURVEY AND ANALYTICAL PROCEDURES

Plum Brook Reactor Facility

2036-SR-01-0 


\section{D.1 Project Health and Safety}

The proposed survey and sampling procedures were evaluated to ensure that any hazards inherent to the procedures themselves were addressed in current job hazard analyses. Prior to on-site activities, a pre-job integrated safety management checklist was completed with input from the licensee and discussed with field personnel. Additionally, upon arrival at the site, contractor representatives provided the Oak Ridge Institute for Science and Education (ORISE) staff with general safety information within the project area as well as a confined-space briefing. The planned activities were thoroughly discussed with site personnel prior to implementation, to identify hazards present. ORISE also had a site escort at all times to assist with identifying specific SU information as well as provide general labor support. All survey and laboratory activities were conducted in accordance with Oak Ridge Associated Universities (ORAU) health and safety and radiation protection procedures.

\section{D.2 Calibration AND Quality Assurance}

Calibration of all field and laboratory instrumentation was based on standards/sources, traceable to National Institute of Standards and Technology (NIST).

Analytical and field survey activities were conducted in accordance with procedures from the following documents of the Independent Environmental Assessment and Verification (IEAV) Program:

- Survey Procedures Manual (ORISE 2008)

- Laboratory Procedures Manual (ORISE 2011a)

- Quality Program Manual (ORAU 2011)

The procedures contained in these manuals were developed to meet the requirements of U.S. Department of Energy (DOE) Order 414.1C and the U.S. Nuclear Regulatory Commission (NRC) Quality Assurance Manual for the Office of Nuclear Material Safety and Safeguards and contain measures to assess processes during their performance.

Quality control procedures include the following:

- Daily instrument background and check-source measurements to confirm that equipment 
operation is within acceptable statistical fluctuations.

- Participation in Mixed Analyte Performance Evaluation Program (MAPEP), NIST Radiochemistry Intercomparison Program (NRIP), and Intercomparison Testing Program (ITP) Laboratory Quality Assurance Programs.

- Training and certification of all individuals performing procedures.

- Periodic internal and external audits.

\section{D.3 Survey Procedures}

\section{D.3.1 SURFACE SCANS}

Scans for elevated gamma radiation were performed using $2 \times 2 \mathrm{NaI}(\mathrm{Tl})$ scintillation detectors by passing the detector slowly over the surface. The distance between the detector and surface was maintained at a minimum. For interior building scans the $\mathrm{NaI}$ detectors were also coupled to data loggers enabling real-time recording in one-second intervals (if available). For outdoor scans detectors were coupled to global positioning system (GPS) units enabling real-time recording in onesecond intervals of both geographic position and the gamma count rate. Position and gamma count rate data files were transferred to a computer system, positions differentially corrected, and the results plotted on geo-referenced aerial photographs or plot plans of the facility. Positional accuracy was within 0.5 meters at the $95^{\text {th }}$ percentile. Histograms were generated for other SUs in which only the count rates were recorded.

Specific scan minimum detectable concentrations (MDCs) for the $\mathrm{NaI}$ detectors were not determined as the instruments were used solely as a qualitative means to identify elevated gamma radiation levels in excess of background. The identification of elevated radiation levels that could exceed the site criteria were determined based on an increase in the audible signal from the indicating instrument. Locations of elevated activity identified on structural surfaces were marked for additional investigation with gas proportional, small area $\left(126 \mathrm{~cm}^{2}\right)$ hand-held detectors.

Structural surface scans were performed by passing the detectors slowly over the surface while the distance between the detector and the surface was maintained at a minimum. Small area $\left(126 \mathrm{~cm}^{2}\right)$ gas proportional, hand-held detectors (with a $0.8 \mathrm{mg} / \mathrm{cm}^{2}$ window) were used to scan the floors, walls, and other structural surfaces of the selected Survey Unit (SU) areas. Identification of elevated 
radiation levels is based on increases in the audible signal from the recording and/or indicating instrument.

\section{D.3.2 Surface Activity Measurements}

Measurements of total activity levels were performed using small area gas proportional detectors coupled to portable ratemeter-scalers. Count rates, which were integrated over one minute with the detector held in a static position, were converted to activity levels of $\mathrm{dpm} / 100 \mathrm{~cm}^{2}$ by dividing the count rate (in counts per minute) by the physical detector area of $126 \mathrm{~cm}^{2}$, and by the total weighted efficiency $\left(\varepsilon_{\mathrm{i}} \times \varepsilon_{\mathrm{s}}\right)$ based on the applicable Radionuclide of Concern (ROCs) per survey unit (see formula below). Individual building material-specific background values were not subtracted from the confirmatory measurements in order to match the licensee's conservative Final Status Survey data reporting procedure. The confirmatory measurement data represent gross activity levels for the remaining structures and surfaces.

$$
E_{\text {weighted }}=\left(E s_{R 1}\right)\left(E i_{R 1}\right)\left(f_{R 1}\right)+\left(E s_{R 2}\right)\left(E i_{R 2}\right)\left(f_{R 2}\right)+\ldots .\left(E s_{R n}\right)\left(E i_{R n}\right)\left(f_{R n}\right)
$$

Multiple instruments were used during survey activities. The average $2 \pi$ instrument efficiencies $\left(\varepsilon_{i}\right)$ were as follows: 0.44 for the gas proportional detectors calibrated to technetium-99, 0.51 for strontium-90, and 0.41 for thorium-230. The source efficiency factor $\left(\varepsilon_{\mathrm{s}}\right)$ was 0.25 for alpha contaminants. Both 0.25 and 0.50 were used for the beta contaminants, dependent upon the beta energy level of the contaminant(s) within specific survey units.

\section{D.3.3 SOIL SAMPLING}

Approximately 0.5 kilogram of soil was collected at each ORISE sample location. Samples were placed in a plastic bag, sealed, and labeled in accordance with ORISE survey procedures.

\section{D.4 Radiological ANALysis}

\section{D.4.1 GAMMA SPECTROSCOPY}

Samples were dried, mixed, crushed, and/or homogenized as necessary, and a portion sealed in a 0.5-liter Marinelli beaker or other appropriate container. The quantity placed in the beaker was chosen to reproduce the calibrated counting geometry. Net material weights were determined and the samples counted using intrinsic germanium detectors coupled to a pulse height analyzer system. Background and Compton stripping, peak search, peak identification, and concentration calculations 
were performed using the computer capabilities inherent in the analyzer system. All total absorption peaks (TAP) associated with the ROCs were reviewed for consistency of activity. TAPs used for determining the activities of ROCs and the typical associated MDCs for a one-hour count time were:

\begin{tabular}{|c|c|c|}
\hline \multicolumn{3}{|c|}{ Table D-1. MDC Derived from Total } \\
Absorption Peak \\
\hline Radionuclide & TAP (MeV) & MDC (pCi/g) \\
\hline Co-60 & 1.173 & 0.10 \\
\hline Cs-137 & 0.662 & 0.05 \\
\hline
\end{tabular}

Spectra were also reviewed for other identifiable TAPs.

\section{D.4.2 SR-90 ANALYSIS}

Samples were homogenized and dissolved by a combination of potassium hydrogen fluoride and pyrosulfate fusions. The fusion cakes were dissolved and strontium was coprecipitated on lead sulfate. The strontium was separated from residual calcium and lead by reprecipitating strontium sulfate from EDTA at a $\mathrm{pH}$ of 4.0. Strontium was separated from barium by complexing the strontium in DTPA while precipitating barium as barium chromate. The strontium was ultimately converted to strontium carbonate and counted on a low-background gas proportional counter. The typical MDC for a one gram sample and a 60 -minute count time was $0.80 \mathrm{pCi} / \mathrm{g}$.

\section{D.4.3 DETECTION LIMITS}

Detection limits, referred to as MDCs, were based on 95\% confidence level via NUREG 1507 method. Because of variations in background levels, measurement efficiencies, and contributions from other radionuclides in samples, the detection limits differ from sample to sample and instrument to instrument. 